\title{
Hazır Giyim Sektöründe Faydacı ve Hedonik Tüketimin Moda Liderliği Üzerine Etkisinin İncelenmesi ${ }^{1}$
}

\author{
Analyzing the Effect of Utilitarian and Hedonic Consumption on Fashion \\ Leadership in the Apparel Sector \\ 10.29023/alanyaakademik.355478
}

\author{
Aydın KAYABAŞI \\ Doç.Dr., Dumlupinar Üniversitesi, IIBF İsletme Bölümü, (aydinkayabasi@dpu.edu.tr) \\ Hakan KİRACI \\ Yrd.Doç.Dr., Muğla Sıtkı Koçman Üniversitesi, Fethiye İşletme Fakültesi, Ulus.Tic.ve Lojistik \\ Bölümü, (hakan.kiraci@yahoo.com)
}

\begin{abstract}
ÖZET
Anahtar Kelimeler: $\quad$ Tüketicilerin tüketim tarzlarl, hedonik ve faydacı tüketim ile moda liderliği davranışları arasındaki ilişsileri belirlemeye yönelik olan bu araştırma,

Hedonik Tüketim

Faydacı Tüketim

Moda Liderliği

Moda Yenilikçiliği

Gönderim:

17.11.2017

Kabul:

25.01.2018 ilişkisel ve betimsel araştırma modelinde kurgulanmıştır. Bu çerçevede tüketim tarzı olarak yaygın bir şekilde ele alınan hedonik ve faydacı tüketim ile moda liderliğini açıklayan moda yenilikçiliği ve moda fikir liderliğ arasındaki ilişkiyi ve tüketicilerin ele alınan değişkenler bazında ortak özelliklerinin açılanmasına yönelik kümelerin hangi özelliklere sahip olduğu belirlenmeye çalışılmaktadır. Araştırmanın örneklemini 18 yaşından büyük tüketiciler oluşturmaktadır. Araştırmanın örneklemi 450 birimden oluşmakta ve bu örneklem büyüklüğ̈̈ güven aralı̆g formülüne göre belirlenmiştir. Araşstırmanın veri toplama tekniği yapılandırılmış ankettir. Araştırma katılımcılarına kolayda örnekleme yöntemine göre ulaşılmıştır. Araştırma verileri karşılıklı görüşme şeklinde gönüllü katılımcılardan anketörler aracılığıla elde edilmistir. Elde edilen veriler tanımlayıcı ve yorumlayıcı çok değişkenli istatistiksel analiz teknikleriyle analiz edilmiştir. Araştırma hipotezlerinin test edilmesinde yapısal eşitlik modelinden yararlanılmıştır. Ayrıca birimlerin doğal küme yapıları k-means kümeleme analiziyle test edilmiştir. Analizler sonucunda, hedonik tüketimin moda ürün satın almayl, modayl takip etmeyi ve moda fikir liderliğini etkilediği belirlenmistir. Faydacı tüketimin ise, moda ürün satın almayı ve modayı takip etmeyi etkilemediği; moda fikir liderliğini etkilediği belirlenmiştir. Kmeans kümeleme analizi sonucunda ise, ü̧̧ ayrı küme yapısı olduğu belirlenmiştir.
\end{abstract}

\footnotetext{
${ }^{1}$ Bu çalışma, 28-30 Eylül 2017 tarihlerinde Trabzon ilinde düzenlenen 22. Ulusal Pazarlama Kongresinde sunulan "Hazır Giyim Sektöründe Moda Liderliğinin Faydacı ve Hedonik Tüketimle İlişkisinin İncelenmesi” isimli özet bildirinin genişletilmiş halidir.
} 
Keywords:

Hedonic

Consumption

Utilitarian

Consumption

Fashion Leadership

Fashion Innovation

\begin{abstract}
Relationship among consumers' consumption styles, hedonic / utilitarian consumption and fashion leadership is analysed in this study, therefore descriptive and relational research methods are preferred. In this framework, it is trying to be determined the relationship between hedonic /utilitarian consumption and fashion leadership. After analyzing the relationship between the variables of the study, clustering analysis is performed on the basis of the variables discussed. In the study, fashion leadership is handled as fashion innovation and fashion opinion leadership whereas consumption style is examined as hedonic and utilitarian consumption. The sample of the research is composed of consumers who are over 18 years old. The sample of the research consists of 450 units and this sample size is determined according to the confidence interval formula. The survey's data collection technique is a structured questionnaire. Research participants were selected by easy sampling method. The research data were collected through dual conversation pollster with volunteer participants. The obtained data were analyzed by descriptive and interpretive multivariate statistical analysis techniques, structural equality model was used to test research hypotheses. In addition, the natural cluster constants of the units were tested by k-means clustering analysis. As a result of the analyzes, we found that hedonic consumption had an effect on buying fashion products, trendiness and fashion opinion leadership. We also found that utilitarian consumption had no effect on buying fashion products and trendiness whereas it had an significant effect on fashion opinion leadership. Finally we found three cluster structures as a result of $K$-means clustering analysis.
\end{abstract}

\section{GíRIŞ}

Günlük yaşantımızda kültürel yaşamı kökten değişstiren unsurlar olarak biçim (modes), popülarite (vogues), heves (fads), moda (fashion), hırs (rages) ve çılgınlıklar (crazies) şeklindeki ifadelerle sürekli karşılaşılmaktadır (Abrahamson, 1996:254). Modern yaşamdaki tüketiciler gelir, eğitim, bireyselleşme, yaşam tarzının büyük değişimiyle yüksek kalitenin önemli hale gelmesi ve kadınların ekonomik yaşama daha fazla katılımlarıyla hazır giyim tüketiminde yeni ve çeşitli eğilimler göstermektedir. $\mathrm{Bu}$ koşullarda, moda endüstrisinin müşterilerin değişen davranış ve ihtiyaçlarını tahmin etmesi ve anlaması, pazardaki ihtiyaçlara dönük yeni moda ürünleri geliştirerek piyasaya sürmesi temel bir adım halini almıştır (Ryou, 2001:403).

Moda uygarlığın temel sanatlarından birisi konumundadır (Azuma ve Fernie, 2003:414). Uygarlığın gelişimi doğrultusunda oluşan moda sektörü ise, küreselleşmenin en çok kendini gösterdiği ve dünya üzerindeki tek tipleşmeyi destekleyen sektörlerin başında gelmektedir. Teknolojinin gelişimiyle, medya ve kitlesel iletişim araçlarının giderek daha fazla yaygınlaşmasıyla birlikte moda kavramının günlük yaşantımıza kolaylıkla girdiği gözlenmiştir. Modanın gelişmesi rol oynayan birincil unsur giyim-kuşam ve bunların aksesuarlarıdır (Kasapoğlu Akyol, 2010:188). Giysi, insanın üzerinde taşıdığı bir ürün olarak değerlendirilmektedir. Giysi, aksesuarlarıyla birlikte insanı kuşatmaktadır (Çivitçi, 2004:3). İnsanlar, utanma duygusu, korunma ihtiyacı ve dekoratif amaçlı giyinmektedir. "Gösterge sistemi" olarak giysilerle kişinin kendisini ifade ettiği ve çevresine bazı mesajlar verdiği ifade edilmektedir. Giysilerin araç olarak kullanıldığı bu iletişimle kişi duygu, düşünce ve inançlarını yansıtarak diğer insanlar tarafından anlaşılmak istenmektedir (Kasapoğlu Akyol, 
2010:188). Modayı çeşitli bilim dallarınca ele alınan bir konudur (Çivitçi, 2004:10). Moda kavramı, McCracken'a göre (aktaran, Kasapoğlu Akyol, 2010:188) kültürü inceleyen bilimler altında; Blumer'a göre (Aktaran, Kasapoğlu Akyol, 2010:188) ise, hem sosyal hem de bireysel bir kavram olarak sosyoloji ve psikoloji bilim dalları içerisinde incelenmesi gereken bir olgudur. Sosyologlar modayı, toplumun alt katmanlarındaki insanların üst katmanlarda yer alan insanları taklit etmelerinden kaynaklanan bir olgu olarak ele almaktadır. Ekonomik bağlamda ise, sürümü kolaylaştıran bir etken olarak kabul edilmektedir (Çivitçi, 2004:10).

Barınma, beslenme ve giyim, insanların temel gereksinimlerindendir. Giyime duyulan gereksinim ilk çağlarda insanların vücutlarını doğanın etkilerinden koruma düşüncesinden doğmuştur. Daha iyi ve güzeli arama duygusu, yıpranan, eskiyen giysinin yerine aynısını değil de, farklısını edinme isteği ile moda başlamıştır. Moda, genelde sanayi sonrası çağa özgü bir olgu olarak düşünülse de gerçekte çok eskilere dayanır. İnsanlığın yaşamına tanıklık eden belgeler ve kalıntılar yaşamın bir moda sergisine benzediğini göstermektedir (Megep, 2008:4,5). Giysi/giyinme biçimleri toplumsal etkileşimde, iletişim bağlamında bir sembol olarak kullanılmaktadır. Bu semboller, bireyin içinde bulunduğu toplumsal, kültürel, siyasal ve ekonomik yapıda anlam üretirler. Bu şekilde, kimliklerin toplumsal, ekonomik, siyasal içerim ve ifadelerinde önemli rol oynarlar. Kendini ifade etmek, sözsüz bir iletişime dayanarak giysiler aracılığıyla anlamları paylaşmak ve farklı kimlikler oluşturmaktır. Dolayısıyla moda, bireyin yaşam tarzına uygun olarak alabileceği görünümlerin ifadesidir (Gençtürk Hızal, 2003:66). Moda satın alma, duygusal ve psikolojik çağrışımlarca zengindir. Moda giysiyle ilgili çoklu duyusal imgeleme yoluyla önem kazanan ve zihinsel aktiviteye sahip bir tüketici ürünüdür. Giyilen giysi, birisiyle ilgili birşeyler söyleyebilmenin en kolay yoludur (Ersun ve Yıldırım, 2010:314).

Moda giyim, sahipliğe ilişkin özellikleri ile kişiye toplumda önemli bir rol sağlayabilmektedir (O’Cass, 2004:869). Bu kapsamda, moda liderinin yeni modanın yayılımında anahtar bir role sahip olması pazarlama da önemli bir yer tutmaktadır. Moda lideri ortalama bir alıcıdan daha erken yeni moda trendler hakkında bilgi sahibi olmaktadır. Dolayısıyla pazara girişinden sonra yeni moda ürünler satın almaktadır. Yeni modanın yayılımında diğer tüketiciler üzerine etkisi oldukça önemlidir. Hazır giyim pazarlamacılarının moda liderlerine ulaşması ve bu tüketicilere yönelik başarılı bir şekilde satış gerçekleştirmesi oldukça önemlidir (Goldsmith, Freiden and Kilsheimer, 1993:402). Summers (1970) moda liderliğinin daha iyi anlaşılmasına yönelik bir araştırma yürütmüştür. Moda liderlerinin kimliklerinin, demografik, sosyal, tutumsal ve konu yönelimli özelliklere göre geliştirildiğini belirlemiştir. İlgili çalışmada, moda liderlerine moda dergilerinin etkisi tartışılmıştır (Bailey and Seock, 2010:43).

Moda liderleri bir tüketici grubu olarak ele alınıp sınıflandırıldığında; moda yenilikçileri, moda fikir liderleri, yenilikçi iletişimciler ve izleyiciler olmak üzere -moda değişim etkenleri olarak isimlendirilen- dört moda tüketici grubu ifade edilebilmektedir. Moda yenilikçileri, yeni moda elbiseleri giyerler ve moda ürünlerinin genelde ilk alan tüketiciler arasındadırlar. Moda fikir liderleri, modaya uymayla diğerlerini etkileme ve onaylarını alarak yenilikçi bir modayı meşrulaştırmaktadırlar. Yenilikçi moda iletişimcileri, yeni modalara uymada ilkler arasında bulunmayan ancak diğerlerinin moda kararlarını kasıtlı olarak etkilemeyi kabul eden tüketicilerdir. Son olarak moda izleyicileri ise, modayı kabulün yoğunlaşmasına kadar yeni bir elbiseyi giymeyen ve almayan kişilerdir. Moda izleyicileri, sıklıkla taklit edilmiş ürünleri satın almayı düşünür ve en büyük grubu oluştururlar (Workman ve Studak, 2006:77, Studak ve Workman, 2004:67, Cho ve Workman, 2011:367).

Moda giyim sektörünün büyüklüğü ve modanın tüketim tercihlerinde oluşturduğu etkiler oldukça fazladır. Dolayısıyla moda giyim ve tercihlerin nasıl şekillendiği açıklanması gereken 
unsurlar arasında yer almaktadır (Jones, Reynolds and Arnold, 2006;974).. Alışverişin hedonik ve faydacı değerler sağladığına ilişkin görüş, pek çok araştırmayla desteklenmektedir (Jones, Reynolds and Arnold, 2006, Lim and Ang, 2008; Okada, 2005;Babin, Darden and Griffin, 1994). Modern tüketim toplumlarında tüketim olgusunun taşıdığı anlam, temel ihtiyaç ve isteklerin karşılanmasından çok; duygusal haza dayalı ve sembolik içeriklerle açıklanmaya başlanmıştır. $\mathrm{Bu}$ kapsamda, tüm pazarlama faaliyetlerinde, ürünlerin jenerik değerinden çok sağlanan haz, duygusal anlam ya da sembolik değerlerine ağırlık verilmeye başlanmıştır (Özgül, 2011). Diğer taraftan tüketim sonucunda belirli bir faydanın elde edilmesine dayalı şekilde hareket etme eğilimi de yaygındır. Bu bağlamda hedonik tüketim değeri, alışveriş deneyiminin çoklu-algılayıcı yapısı, fantezi ve duygusal özelliklerinden elde edilen değeri yansıtırken; faydacı tüketim değeri ise alışverişin daha görev yönelimli, bilişsel ve duygusal olmayan çıktısı olarak görülebilen ve etkili bir şekilde ürünler ve ilişkili bilgilerin edinimini yansıtmaktadır. Genel anlamda faydacı alışveriş, bir alışveriş deneyiminin görev yönelimli değerini açıklarken; hedonik tüketim ise görev yönelimli faaliyetlerden bağımsız bir şekilde elde edilen alışveriş deneyiminin kendisinde bulunan değeri ifade etmektedir (Jones, Reynolds and Arnold,2006).

\section{TEMEL BİR İLGI ALANI OLARAK MODA}

Moda temelde yenilikle ilgilidir ve bu kavram; modayı benimseyenlerin, başkalarına kendisini ifade etmeleri için alışılmışın dışında bir yolu belirtmektedir. Moda, sosyal olarak eşsizliğin kabul edilebilirliği içinde bireyselliğe ilişkin bir arayışı temsil etmektedir (Michon vd., 2007:490). Yenilikçilik sosyal bir sistemin çoğu üyelerinden daha önce yeni şeyleri benimseme ve karşılama eğilimidir. Çoğu alandaki araştırmacılar, nasıl ve niçin bu davranışların ortaya çıktığını ve diğer psikolojik özelliklerin bunlarla nasıl ilişki içerisinde olduklarını tanımlamak ve açıklamak için yenilikçilerin özelliklerini incelemektedir. Yenilikçilik pazarlama alanında oldukça önemlidir ve bu önem nedeniyle, yeni ürünlerin başarısı için tüketiciler incelenmektedir. Bu konunun önemli olan bir yanı, yenilikçiliğin fiyat duyarlılı̆̆ına ilişkindir. Nitekim, fiyata duyarsız olan tüketiciler aynı ürünlere duyarlı olanlardan daha fazla ödeme yapmaya isteklidir (Goldsmith vd., 2005:501-502).

Tüketici davranışı, karmaşık bir olgudur ve insan davranışları farklı bir ürün satın aldıklarında farklılaşmaktadır (Knox and Walker, 2001:112). Tüketici davranışının bir parçası olan satın alma davranışı çoğu bireysel ve çevresel faktörlerden etkilenmektedir. Kültür ve aile gibi çevresel faktörler yanında yaşam tarzı, belirli bir objeye karşı tutum gibi bireysel faktörler satın alma kararlarını etkilemektedir. Pazar bölümlendirme karar alma sürecinin anlaşılmasına yönelik temel bir parça olarak diğer bir değişkeni oluşturmaktadır. Bölümleme (segmentation) bir tüketiciler pazarının tanımlanabilmesi ve tüketici özelliklerine dayalı olarak Pazar bölümlerine ayrılması önermesine dayanmaktadır (McKinney at.al., 2004:389).

Giyim yaşamımızın merkezidir. Doğumdan sonra vücudumuzu sarmak için, ve yaşantımızın çeşitli dönemlerinde fonksiyonel ve iletişim özellikleri olarak kullanılmaktadır. Giyim çıplak vücut ve sosyal dünya arasında kişisel bir sembol olarak aracıllk eder. Uzun zamandan beri pazarlamacılar tüketicilerin öz kimliklerini oluşturmak (self-identity) ve bunu diğerlerine iletmek için giyimi kullandıklarını bilmektedir. Tüm kimlik türleri etnik kimlikler ve cinsel kimliklerden alt kültürlerin tüketim kimliklerinin birikimine doğru değişen giyim tüketimi aracılığıyla yapılandırılmaktadır (Peters, Shelton and Thomas, 2011:292,293).

Moda kavramı, çok yaygın olarak kullanılmasına karşılık endüstri içerisinde kendisini giysi, aksesuar ve ayakkabıların tasarım, üretim, satış ve promosyon alanlarından gösterir. $\mathrm{Bu}$ medya araçlarında kullanım açısından da kendisini bu şekilde gösterir (Çivitci, 2004:4). 
Yenilikçiliğin tüketicilerin spesifik bir ürüne ya da ürün kategorisine yönelik yenilikçi olma eğilimi anlamında spesifik-ilgi alanı olduğuna yönelik deliller vardır. Ürün kategorileri arasında yenilikçi davranışı genelleştirmenin zor olduğuna inanılmaktadır. $\mathrm{Bu}$ davranışın alanın spesifik bir ürün kategorisiyle sınırlandırıldığında daha iyi anlaşılması ve tahmin edilmesi sağlanabilecektir. Moda yeniliğin yayılmasında çok önemli olabilecek bir alan bulur ve yeni stillerin giriş sıklığı yenilikçilik üzerine diğer çalışmaların yayılmasına yönelik son derece arzu edilebilir bir moda pazarı ortaya çıkarır (Jordan and Simpson, 2006:33).

Moda kavramına literatürde farklı tanımlar getirilmiştir. İyi bir tanım geliştirmek amacıyla, Sproles (1974'den aktaran, Vieria, 2009: 179-180) modayı modern bir teori çizen üç nokta olarak ifade etmektedir. İlk nokta olarak genelleştirilmiş moda kavramı - moda materyal olan ve materyal olmayan bir kapsam dizisinde belirtilen geniş bir davranışsal olgu olarak tanımlanabilir. İkinci nokta, moda: bir nesne ve bir süreç - moda bir nesne ve bir davranışsal süreç olarak kavramsallaştırılabilir. Üçüncü nokta ise moda süreci mekanizması - moda süreci bir sosyal etki ve yayılım süreci olarak mekanistik olarak karakterize edilebilir.

Son yirmi yıldır, moda tüketicileri; moda liderleri, yenilikçiler, izleyiciler ve benimsemeyenler şeklinde gruplandırılmış ve bunların yönlendirici ve duygusal gelişimlerini anlamak ve demografik ve yaşam tarzı profillerini ortaya çıkarmak çalışmaların odağı olmuştur (Michon vd., 2007:490). En son moda trendlerini takip eden tüketiciler, modaya ve aynı zamanda plansız satın almaya yüksek ilgilenim düzeyi bulunan bireyler şeklinde nitelendirilmektedir. Modaya yüksek ilgilenim düzeyinin, deneyim ve duyusal sinyaller oluşturması nedeniyle plansız satın alma sürecinde bireylere uyarıcılar sağladığı belirlenmiştir. Farklı bir açıdan bakıldığında, moda odaklı plansız satın alma sıklıkla olumlu duyular ve hazcı tüketim eğilimleriyle ilişkilendirilmektedir (Virvilaite vd., 2011:1331). Ayrıca, plansız satın alıcıların en sık aldığı parçaların kozmetik, takı, ayakkabı ve giyimi kapsayan görünüme ilişkin ürünler olduğu bazı araştırmalarda ifade edilmektedir. Bu tüketicilerin satın aldıkları görünüme ilişkin ürünleri başkaları üzerinde izlenim bırakmak ya da bıraktıkları izlenimleri arttırmak amacıyla kullandıkları ifade edilmektedir (Attmann ve Johnson, 2009:268).

Moda tüketici grupları; moda değişim etkenleri ve moda izleyicilerini içermektedir. Moda değişim etkenleri arasında yeni modayı giyen ve satın alarak moda değişimini ilk benimseyen tüketiciler oluşturmaktadır. Bu grup, giyim ve satın alma için diğerlerini ikna eden ve tüm fonksiyonları karşılayanlardır (Workman ve Lee, 2011:35, Bailey ve Seock, 2010:43). Moda değişim etkenleri, sosyal durum ve prestije moda izleyicilerden daha fazla önem vermektedir. Örneğin; imaj veya modanın sembolik görünümü moda değişim etkenlerinde çok daha önemli görülmektedir. Giyim/kullanım arzuları ve diğerlerine ifade edeceği görünümlerinin tutarlılığı ile moda değişim etkenleri daha fazla görünüm yönetimi davranışları uygular ve daha fazla beden ve görünümlerinin bilincindedir (Workman ve Lee, 2011:35).

Moda liderliği; moda yenilikçileri ve moda fikir liderliği olmak üzere iki boyutta ele alınmaktadır (Stith ve Goldsmith, 1989; Sproles ve Burns, 1994; Workman ve Studak, 2006; Kang ve Park-Poaps, 2010; Cho ve Workman, 2011). Moda yenilikçileri, kişisel olmayan iletişime dayalı olmadan yapılan satın alma eğilimini ve diğer tüketicilerden çok daha önce yeni moda ürünleri satın alma eğilimini ifade etmektedir. Moda yenilikçileri, yeni bir moda akımı ya da stili ilk benimseyen tüketiciler olarak, ürünlerin pazara sürüldüğü ilk dönemde farkındalık oluşturmaları açısından ve yeni bir modanın yoğun bir şekilde benimsenmesini etkileyen bireyler oldukları için oldukça önemlidirler. Moda fikir liderliği ise, diğer bireylerin davranış ya da tutumlarını biçimsel olmayan bir şekilde etkileyebilmeye ilişkin göreceli bir sıklıktaki isteği ifade etmektedir. Bu bağlamda; erken benimseyenler, sistemde yer alan 
bireyler arasında en yüksek fikir liderliği potansiyeline sahip olan kişilerdir ve yeni modanın kitlesel olarak benimsenmesinde önemli oranda etkileri bulunmaktadır (Workman ve Studak, 2006; Sproles ve Burns, 1994).

\subsection{Moda Liderliği}

Modern toplumlar, sahip oldukları güçlü bir inançla kategorize edilmektedir. Bu yaşamın anlamı, başarı ve memnuniyetin elde edilemeyen ya da sahip olunan şeyler açısından sıklıkla değerlendirilen bir görüşe ilişkindir. Ayrıca bu sahip olduklarıyla bireysel bir ilişki tarafından sağlanan faydaya ilişkindir. Böylece, bireyler sıklıkla sahip oldukları açısından kendilerini ve diğerlerini tanımlarlar. Sahip oldukları kişisel vasıflar, bağlantılar ve ilgilere yönelik anahtar semboller olarak hizmet etmeye başlar ve bireysel kimlik sahip olunan materyallerin sembolik anlamlarından etkilenirler. Toplumda önemli bir rol sağlayan bir sahiplik de moda giyimdir (O’Cass, 2004:869). Ayrıca moda liderliği, moda liderinin yeni modanın yayılımında anahtar bir role sahip olmaları yüzünden pazarlama da önemli bir kavramdır. Moda lideri ortalama bir alıcıdan daha erken yeni moda trendler hakkında bilgi sahibi olur ve pazara girişinden sonra yeni moda unsurları satın alır. Bununla beraber diğer tüketiciler üzerine etkisi, yeni modanın yayılımında oldukça önemlidir. Kısaca tanımlamak gerekirse; moda liderliği, diğer insanların giyim nesneleri/biçimi ya da stillerini benimsemesi için yeni moda akımını yönlendirebilme yeteneğini ifade etmektedir (Ryou, 2001:403). Bu bağlamda moda liderleri; diğer tüketicilerden daha fazla modaya ilgisi olan, bazı stilleri seçen ve bazılarını reddeden, kabul edilebilir ve mantıklı yeni görünümler oluşturan, yeni stillerin benimsenmesine yönelik diğer tüketicileri ikna etmede rol oynayan bireyler olarak tanımlanabilmektedir (Belleau vd., 2001:134). Bir başka deyişle moda liderleri, yeni moda eğilimlerine temel oluşturmayı ve diğerlerinin izleyeceği mükemmel standartlar oluşturmayı tercih etmektedirler. Ayrıca moda liderleri, daha iç yönelimli görünseler de, tamamen sosyal normlara uymak zorundaymış gibi görünmek istemeyen bireylerden oluşmaktadırlar. Kişilik özelliklerine göz atıldığında, yeni bir stili benimsemede bir ilk olmaya ilişkin sosyal riski almaya uygun oldukları, diğer tüketicilerden daha fazla belirsizlik üstlenebildikleri, eğlenceli bir yaşam sürme arzusunda oldukları ve heyecana diğer insanlardan daha fazla önem verdikleri gibi tespitler göze çarpmaktadır. Ayrıca moda liderlerinin diğer tüketicilerden daha fazla alışveriş yapma eğilimine sahip oldukları ve görünüş/estetik için daha fazla harcama yaptıkları belirtilmektedir (Belleau vd., 2001:134).

Moda liderliği aynı zamanda pazar bölümüne yönelik standart bir davranış değişkenidir. Tüketiciler moda lideri, moda yönlendiren grup ve modayı izleyen grup olmak üzere iki grupta kategorize edilmektedir. Biçimlendirici grup demografik, psikolojik özellikler ve giyime ilişkin davranış kalıplarıyla izleyici gruptan farklıdır (Ryou, 2001:403).

\subsection{Moda Fikir Liderliği}

Fikir liderleri, kişisel iletişim yoluyla belirli bir alanda diğer kişilerin düşüncelerine etki etmek için çaba harcayan ve bu alanla ilgili olan kişilerdir (Harben ve Kim, 2008:90). Fransız kadın moda fikir liderlerine yönelik yapılan bir çalışma (Vernette, 2004'den aktaran Harben ve Kim, 2008:90); fikir liderlerinin medya reklamlarına yönelik daha olumlu eğilime sahip olmaları nedeniyle, moda medyasının başarılı olmak için fikir liderlerini hedeflemelerinin daha iyi olacağını ifade etmektedir. Bu açıdan fikir liderliği, bilgi aramaya yönelik medyanın kullanımıyla ilişkili bir olgudur. Bu şekilde elde edilen bilgiler, fikir liderlerinin temel bir ağızdan ağza bilgi sağlama kaynağı olarak diğer bireylerin tutumlarını etkilemeleri gerçeğini ortaya çıkmaktadır (Harben ve Kim, 2008:90). 
Fikir liderleri, ileri teknoloji ürünleri kullanmanın yanında teknik olarak da yetkinlikleri bulunan (Shoham and Ruvio, 2008:282):

- Sosyal olarak aktif,

- kitlesel medya tüketicileri olma özelliği,

- bilinçli ya da bilinçli görünümde olmaları,

- kişisel odaklı olmaları,

- kendinden emin olmalar1,

- farklı davranan ve/veya düşünen bireylerden oluşmaları,

- kamu bireyciliği sergilemeleridir.

\subsection{Moda Yenilikçileri}

Tüketici araştırmacılarının yenilikçiliği, herkesin bireysel deneyim kapsamında yeni bazı nesne ya da fikirlere uyum sağladığı için tüm bireylerin sahip olduğu kişisel bir özellik olarak gördükleri ifade edilmektedir Park vd., 2007:203). Böylece yeni ürünler, yeni hizmetler ve yeni uygulamaları alma düzeyi yüksek olan tüketiciler, yenilikçiliği pazarlamacılar açısından yeni bir ürün ya da hizmetin nihai başarısı için son derece önemli olarak görmelerine olanak sağlamaktadır. Yenilikçiliğin iki temel türü, -açık işlem ya da genel yenilikçilik ve özel alan yenilikçiliği- tüketici yenilikçiliğinin ölçülmesi ya da tanımlanmasında kullanılır. Açık işlem yenilikçiliği ya da genel yenilikçilik, yeni deneyimlere açılan bilişsel bir tarzı ifade etmektedir. Bazı araştırmacılar, tüketicilerin yeniliğe uyumlarını tahmin etmede daha kullanılışı özel alan yenilikçilik ölçüm alanını bulmuştur. Ayrıca İnternetten alışverişte; ilişkili özel-alan yenilikçiliğinin, alışverişe yönelik tüketicinin internete uyumu üzerine açıkişlem yenilikçiliğinden daha güçlü bir etkiye sahip olduğu belirlenmiştir (Park vd., 2007:203).

Moda, temelde yenilikle ilgilidir ve modayı benimseyenlerin başkalarına kendisini ifade etmeleri için alışılmışın dışında bir yolu ifade etmektedir. Moda, sosyal olarak eşsizliğin kabul edilebilirliği içinde bireyselliğin arayışını temsil etmektedir (Michon vd., 2007:490). Yenilikçilik, sosyal bir sistemin çoğu üyesinden daha önce yeni şeyleri benimseme ve karşılama eğilimidir (Goldsmith vd., 2005:501-502). Çoğu alandaki araştırmacılar, nasıl ve niçin bu davranışların ortaya çıktığını ve diğer psikolojik özelliklerin bunlarla nasıl ilişki içerisinde olduklarını tanımlamak ve açıklamak için yenilikçilerin özelliklerini incelemektedir (Patterson, Kerrin ve Gatto-Roissard, 2009; Imran vd., 2010). Yenilikçilik pazarlama alanında oldukça önemlidir ve bu önem yüzünden yeni ürünlerin başarısı için tüketiciler incelenmektedir. Bu konunun önemli olan bir yanı, yenilikçiliğin fiyat duyarlılığına ilişkindir. Fiyata duyarsız olan tüketiciler aynı ürünlere duyarlı olanlardan daha fazla ödeme yapmaya isteklidir (Goldsmith vd., 2005:501-502).

Bir pazar boyunca genişleyen ve kabul edilen yenilik yayılımı, sosyal bilimlerdeki araştırmalarda araştırmacıların uzun sürelerden bu yana ilgilerini çekmektedir. Bu yoğun ilgiyle sonuçlanan yayılım araştırması, yayılım teorisi ve benimseme teorisine kavramsal bir çerçeve oluşturmuştur (Jordan ve Simpson, 2006:32-33). Yeni moda bir ürünün başarıs1, moda yenilikçileri tarafından ürün yaşam sürecinin erken dönemlerinde kabulü ile ilişkilidir. Rogers'in uyum teorisine göre, (aktaran Morgan ve Birtwistle, 2009:191) aynı kültür içerisinde olsa bile herkes bir yeniliğe aynı oranda uyum sağlayamaz. Rogers tüketicileri bir yeniliğin toplum içinde farklı oranlarda nasıl yayıldığını açıklamaya yardım eden beş farklı grup içinde kategorize etmektedir. Bunlar

- Yenilikçiler - \%2,5

- Erken benimseyenler - \%13,5

- Erken çoğunluk - \%34 
- Geç çoğunluk - \%34

- Gecikenler - \%16

Rogers'ın teorisinin (aktaran Morgan ve Birtwistle, 2009:191) incelenmesi üzerine iki ilginç durum fark edilmiştir. İlk olarak, tüketicilerin yaklaşık \%16'lık kısmı (yenilikçi ve erken benimseyenler) yüksek derecede yeni trendlerin farkında ve moda bilinci olanlardır. Bunlar yeni trendlerin farkındadır, bunları değerlendirir ve kısa bir sürede benimserler. İkinci olarak, alışverişçilerin üçte ikisi erken ve geç çoğunluğa aittir. Bunlar, yeni trendlerle ilgilenirler ancak bunları hızlı bir şekilde benimseme eğilimleri düşüktür; bu yüzden herkes, moda trendleri hakkındaki dikkatlerini gecikenlere (\%16) saklarlar.

\section{HEDONIK ve FAYDACI TÜKETIM}

Tüketim stilleri; tüketim sürecinde, tüketicileri belirli bir şekilde davranmaya iten süreçlerdir. Alışveriş stilleri temelde faydacı ve hedonik nedenlerle yönlendirilmektedir. Geleneksel tüketici davranışı araştırmacıları, alışverişi faydacı bakış açısından önemli ölçüde akılcılık temelinde işleyen bir süreç olarak ele almaktadırlar. Alışveriş, temel olarak zihinsel olarak işleyen ve belirli bir ürün elde edilmesine yönelik bir ihtiyaç tarafından yönlendirilen bir süreç olarak ele alınmaktadır. Buna karşın; son zamanlarda araştırmacıların, alışveriş olgusunun bilişsel süreçlerini incelemek yerine boş zaman, eğlence, duygusal ruh halleri ve tatmin gibi alışverişi yönlendiren hedonik değerleri incelemeye başladıkları gözlenmektedir (Kang ve Park-Poaps, 2010).

Tüketim stilleri, hedonik/faydacı tüketim ile moda liderliği (moda yenilikçiliği ve moda fikir liderliği) arasındaki ilişkileri inceleyen daha önceki araştırmalara göz atıldığında; 18 yaşından büyük tüketicileri (Özgül, 2011), üniversite öğrencilerini (Fettahlığlu vd., 2014; Kükrer, www.ktu.edu.tr), Rus ve ABD vatandaşlarının elde edilen sonuçlar açısından karşılaştırıldığı araştırmaları (Griffin vd., 2000), kadın tüketicileri (Kim ve Hong, 2011) ve farklı perakende sonuçları açısından hedonik ve faydacı tüketim ilişkisini (Jones vd., 2006) inceleyen araştırmaların yapıldığı görülmektedir.

\section{ARAŞTIRMANIN AMACI ve YÖNTEMI}

Tüketici karar alma sürecinde duyguların rolü büyüktür. Olumlu duygular belirli bir markaya yönelik olumlu bir davranış ya da tutumla sonuçlanabilir. Her birey tektir ve bu memnuniyetin sağlanması için bireyin kendisine yönelik ihtiyaçlarının karşılanması anlamına gelmektedir. Müşterilere sunulan eşsiz hizmetler aracılığıyla oluşturulan olumlu duygular nedeniyle müşteriler gelecekte daha yüksek fiyat ödemeye daha istekli olabileceklerdir (Baig ve Khan, 2010:63). Moda değişimi tüketicileri sürekli yeni kıyafetler almaları için motive etme amaciyla moda perakendecileri tarafindan planlı bir şekilde demode (obsolescence) yapma olarak görülebilmektedir. Farklı pazar bölümleri vardır ve her biri yeni moda trendlerine sahiptir. Farklı bölümler arasında, genç bölümü en fazla moda tüketimi araştırmasında çalışma hedefi olmaktadır. Bunun nedeni gençlerin cesaretli olmaları, yeni fikirleri deneme arzularıdır ve yeni moda sıklıkla gençlerle başlamaktadır (Law vd., 2004:362). Hazır giyim sektörü moda değişiminin en hızlı yaşandığı ve konumlandırıldığı temel alanlardan birisidir. Hazır giyim sektörünün büyüklüğü ve modayla ilişkili algılanan bir sektör olması araştırmanın yapılmasına dayanak oluşturmaktadır (Erciş ve Türk, 2012:2). Bu kapsamda bu çalışmanın amacı, hazır giyim sektöründe faydacı ve hedonik tüketimin moda liderliği üzerindeki etkisinin incelenmesidir. 


\subsection{Araştırmanın Modeli ve Hipotezleri}

Tüketicilerin tüketim stilleri ile moda liderliği arasındaki ilişkileri belirlemeye yönelik olarak yapılan bu araştırma, ilişkisel ve betimsel araştırma modelinde kurgulanmaktadır. Tüketim stili olarak yaygın bir şekilde ele alınan hedonik ve faydacı tüketim ile moda liderliğini açıklayan moda yenilikçiliği ve moda fikir liderliği arasındaki ilişkiyi ve tüketicilerin ele alınan değişkenler bazında ortak özelliklerinin açıklanmasına yönelik kümelerin hangi özelliklere sahip olduğu belirlenmeye çalışılmaktadır. Son 20-30 yıllık dönemde, moda tüketicileri yaygın bir şekilde incelenmektedir. Bu çalışmalar, moda liderlerini, yenilikçileri, izleyicileri ve benimsemeyenlerin üzerine odaklanmış ve yönlendirici ve duygusal gelişimlerini anlamak ve demografik ve yaşam tarzı profillerini ortaya koymaya çalışmaktadır (Michon vd., 2007:490). En son moda trendlerini takip eden tüketiciler, modaya ve aynı zamanda plansız satın almaya yüksek ilgilenime sahip oldukları şeklinde nitelendirilmektedir. Modaya yüksek ilgilenim düzeyinin deneyim ve duyusal sinyaller oluşturması nedeniyle plansız satın almak için uyarıcılar sağladığı belirlenmiştir. Farklı bir açıdan bakıldığında moda odaklı plansız satın alma sıklıkla olumlu duyular ve hazcı tüketim eğilimleriyle ilişkilendirilmektedir (Virvilaite vd., 2011:1331). Plansız satın alıcıların en sık aldığ1 parçaların kozmetik, takı, ayakkabı ve giyimi kapsayan dış görünüme ilişkin ürünler olduğu bazı araştırmalarda ifade edilmektedir. Bu tüketicilerin satın aldıkları görünüme ilişkin ürünleri, başkaları üzerinde izlenim bırakmak ya da bıraktıkları izlenimleri arttırmak amacıyla kullandıkları ifade edilmektedir (Attmann ve Johnson, 2009:268).

Moda tüketici grupları, moda değişim unsurlarını ve moda izleyicilerini içermektedir. Moda değişim unsurları arasında yeni modayı giyen ve satın alarak moda değişimini ilk benimseyen tüketiciler, giyim ve satın alma için diğerlerini ikna eden ve tüm fonksiyonları karşılayanlardır (Workman ve Lee, 2011:35, Bailey ve Seock, 2010:43). Moda değişim etkenleri sosyal durum ve prestije moda takipçilerinden daha fazla önem vermektedir. Örnek olarak imaj veya modanın sembolik görünümü daha önemlidir. Giyim kullanım arzuları ve diğerlerine ifade edeceği görünümlerinin tutarlılı̆̆ı ile moda değişim etkenleri daha fazla görünüm yönetimi davranışları uygular ve daha fazla vücut ve görünümlerinin bilincindedir (Workman ve Lee, 2011:35). Moda liderliği boyutları; moda yenilikçiliği ve moda fikir liderliği ile alışveriş tarzlarının ilişkisel olarak incelenmektedir (Kang ve Park-Poaps, 2010). $\mathrm{Bu}$ çerçevede bu araştırma kapsamında test edilmek amacıyla ileri sürülen hipotezler ise şu şekildedir;

H1: Hedonik tüketim moda yenilikçiliğini etkilemektedir.

H2: Faydacı tüketim moda yenilikçiliğini etkilemektedir.

H3: Hedonik tüketim moda fikir liderliğini etkilemektedir.

H4: Faydacı tüketim moda fikir liderliğini etkilemektedir.

H5: Bireyler faydacı ve hedonik tüketim ile moda liderliği açısından doğal kümelere sahiptir.

Araştırmanın modeli şekil 1'de gösterilmektedir. 


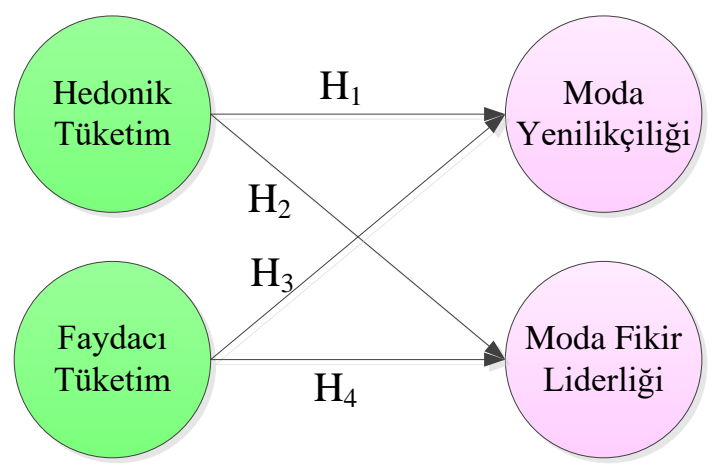

Şekil 1. Araştırmanın Modeli ve Hipotezleri

\subsection{Araştırmanın Örneklemi}

Araştırmanın örneklemini 18 yaşından büyük tüketiciler oluşturmaktadır. Araştırmanın örneklemi 450 birimden oluşmakta ve bu örneklem büyüklüğü, güven aralığ1 formülüne göre $\% 4$ hata oranı üzerinden belirlenmiştir. Araştırma katılımcılarına kolayda örnekleme yöntemine göre ulaşılmaktadır.

\subsection{Araştırmanın Veri Toplama Yöntemi}

Araştırma verileri karşılıklı görüşme şeklinde gönüllü katılımcılardan anketörler aracılığıyla elde edilmektedir. Araştırmanın veri toplama tekniği yapılandırılmış ankettir. Anket formu, katılımcıların genel özellikleri, kıyafet tercihlerinde aradıkları özellikler, kıyafet alırken etkilendikleri medya araçları ve moda liderliği ve tüketim stillerinin incelendiği 4 bölümden oluşmaktadır. Anketin yapılandırılmasında moda liderliği; moda yenilikçiliği (Goldsmith vd., 1993; Goldsmith ve Hofacker, 1991), fikir liderliği (Flynn vd., 1996), hedonik tüketim (Jones vd., 2006) ve faydacı tüketim (Kim, 2006) ölçekleri uyarlanarak kullanılmıştır. Ölçeklerde yer alan ifadelere katılımcıların 5'li likert tipi ölçek yardımıyla (1.kesinlikle katılmıyorum...5.kesinlikle katılıyorum) yanıt vermesi istenmiştir.

\section{BULGULAR}

Araştırmadaki değişkenlerin yapısal geçerliliklerinin incelenmesi amacıyla öncelikle açıklayıcı faktör analizi ve doğrulayıcı faktör analizi kullanılmıştır. Araştırmada tüketim stilleri ile moda liderliği arasındaki ilişkinin incelenmesinde korelasyon analizi ve yapısal eşitlik modeli kullanılmıştır. Değişkenler bazında bireylerin doğal küme yapılarının incelenmesi amacıyla da "k-means kluster" kümeleme analizinden faydalanılmıştır. "Kmeans kluster" analizinin kullanılmasındaki temel amaç, bireylerin incelenecek değişkenler bazında sahip oldukları küme yapılarının belirlenmesi ve kümeler bazında bireylerin genel özelliklerinin açıklanmasını sağlayabilmektir.

\subsection{Tanımlayıcı İstatistiksel Bulgular}

Tanımlayıcı istatistiksel analizler kapsamında araştırma katılımcılarının genel özellikleri, kıyafet tercihlerinde aradıkları özelliklerin neler olduğu ve kıyafet alırken etkilendikleri medya araçlarıyla ilgili özellikleri incelenmektedir. Aşağıdaki incelenen özelliklere ilişkin frekans dağılımları, yüzde, ortalama ve standart sapma değerleri gösterilmektedir. 
Tablo 1. Katılımcıların Genel Özellikleri

\begin{tabular}{|c|c|c|c|}
\hline Demografik Özellikler & Kategori & Fr. & $\%$ \\
\hline \multirow{2}{*}{ Cinsiyet } & Kadın & 183 & 40,7 \\
\hline & Erkek & 267 & 59,3 \\
\hline \multirow{4}{*}{ Yaş } & $<20$ Yaş Arası & 113 & 25,1 \\
\hline & 21-30 Yaş Aras1 & 207 & 46,0 \\
\hline & 31-40 Yaş Aras1 & 97 & 21,6 \\
\hline & $>40$ Yaş Arası & 33 & 7,3 \\
\hline \multirow{3}{*}{ Aile Geliri } & $0-2000 \equiv$ & 92 & 20,4 \\
\hline & $2001-3500 €$ & 216 & 48,0 \\
\hline & $>3501 €$ & 142 & 31,6 \\
\hline \multirow{3}{*}{ Yaşam Yeri } & Büyükșehir & 211 & 46,9 \\
\hline & İl Merkez & 123 & 27,3 \\
\hline & Kasaba/Köy/Diğer & 116 & 25,8 \\
\hline
\end{tabular}

Katılımcıların genel özellikleri incelendiğinde, \%40,7'sinin kadın, \%59,3'ünün erkek katılımcı olduğu, yaş aralıklarının \%25,1'inin 20 yaşından küçük, \%46,0'ının 21-30 yaş aralığıında, \%21,6'sının 31-40 yaş aralığında ve \%7,3'ünün 40 yaşının üzerinde olduğu, gelir düzeylerinin \%20,4'ünün 0-2000 TL, \%48,0'ının 2001-3000 TL ve \%31,6'sının 3501 TL ve üzeri olduğu, yaşam yerlerinin ise, \%46,9'unun büyükşehir, \%27,3'ünün il merkez ce \%25,8'inin kasaba/köy/diğer yaşam yerlerinden oldukları belirlenmiştir.

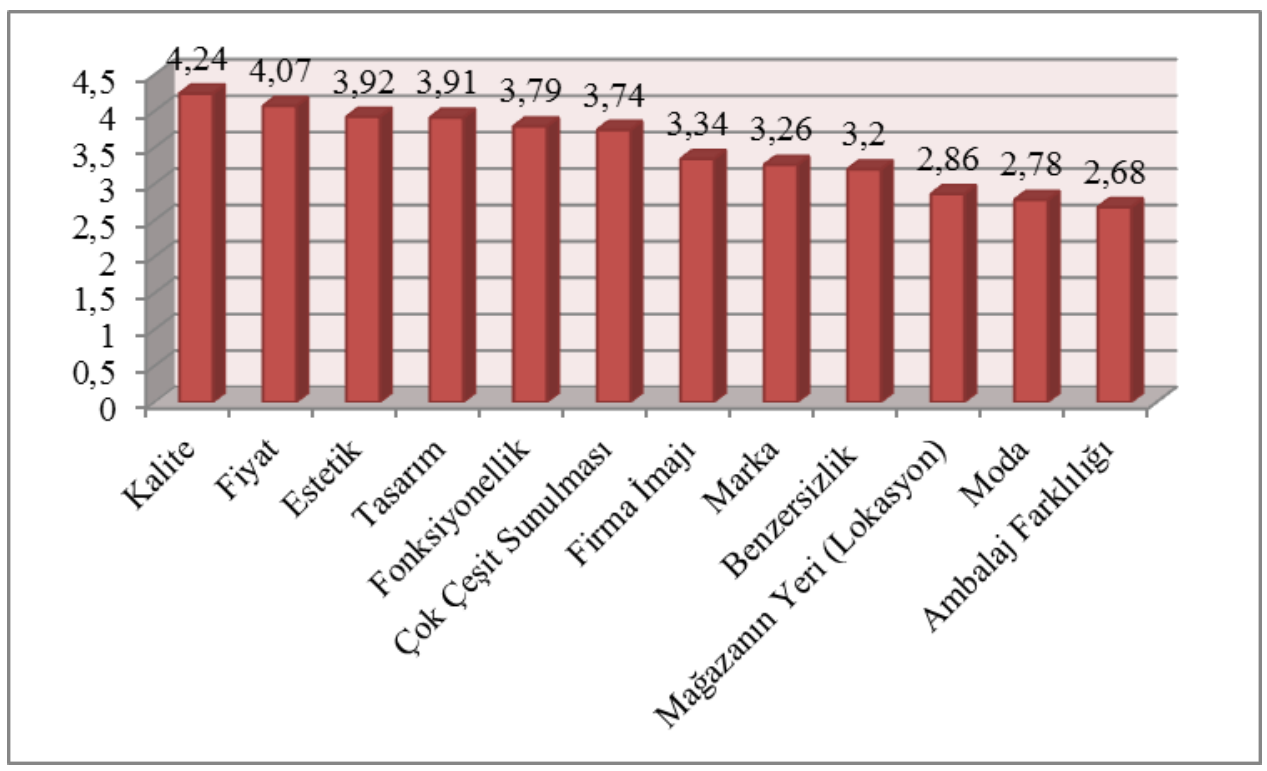

Grafik 1. Kıyafet Tercihlerinde Aranan Özellikler

Araştırmaya katılan bireylerin kıyafet tercihinde aradığı özellikler grafik 1 'de gösterilmektedir. Bu grafik incelendiğinde; katılımcıların kıyafet tercihlerinde ilk beş sırada; kalite, fiyat, estetik, tasarım ve fonksiyonellik özellikleri aradıkları gözlenmektedir. 


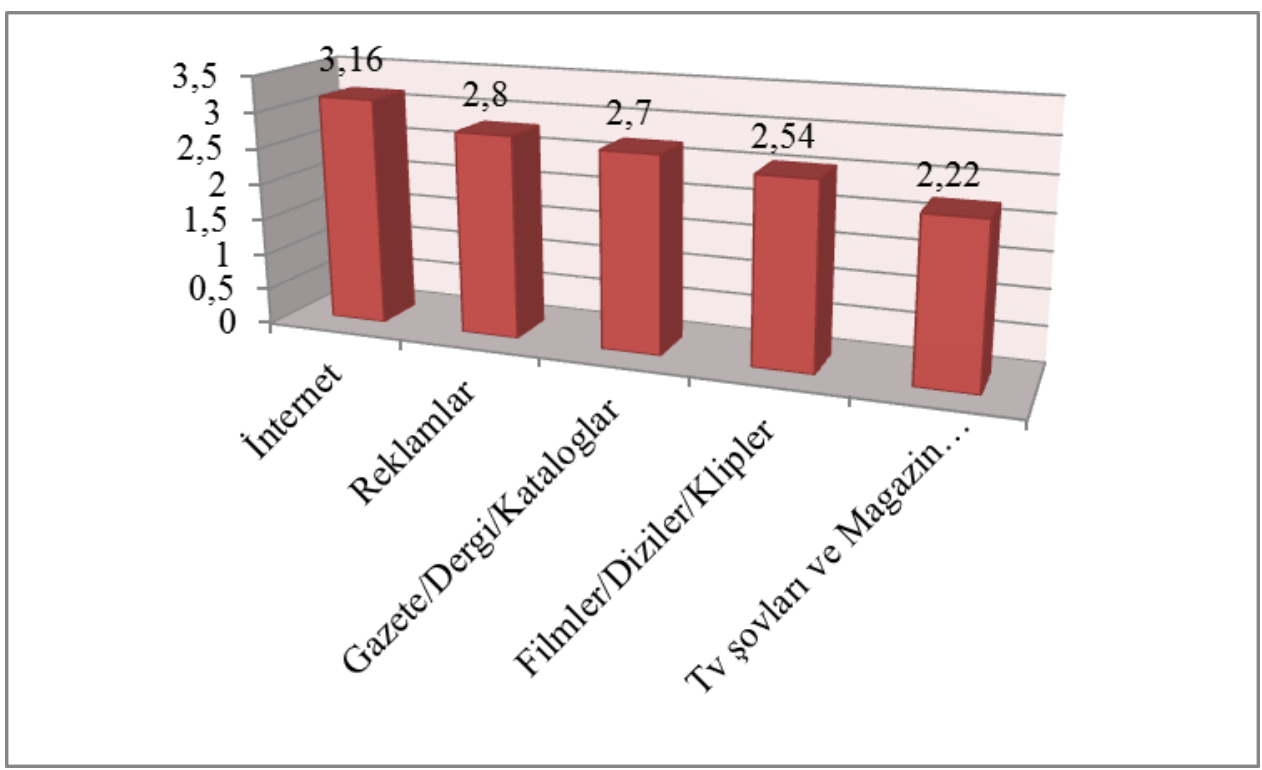

\section{Grafik 2. Etkileyici Medya Kanalı}

Araştırmaya katılan bireylerin kıyafet tercihinde aradığı özelliklerin yanı sıra, katılımcıların kıyafet tercihlerinde etkilendiği medya araçları da ortaya konmuştur. Grafik 2'de yansıtılan bulgulara göre; kıyafet tercihlerinde kişilerin en fazla bilgi edindikleri ve etkilendikleri medya araçlarının internet medyası ve firma reklamlarının olduğu görülmektedir.

\subsection{Açıklayıcı Faktör Analizi}

Yapısal geçerliliğin test edilmesine yönelik yaygın bir şekilde kullanılan faktör analizi, birbiriyle ilişkili çok sayıda değişkeni bir araya getirme yoluyla daha az sayıda ve kavramsal olarak anlamlı yeni değişkenlerin belirlenmesini sağlayan çok değişkenli bir istatistiksel analiz türüdür (Çokluk vd., 2014). Bu kapsamda, araştırmada kullanılan ölçeklerin yapısal geçerliliklerinin test edilmesi amacıyla öncelikle açıklayıcı faktör analizinden yararlanılmıştır. Moda liderliği literatürde moda yenilikçileri ve moda fikir liderliği olmak üzere iki boyutlu yapısal özellikle açıklanan bir değişken olarak ifade edilmektedir (Stith ve Goldsmith, 1989; Sproles ve Burns, 1994; Workman ve Studak, 2006; Kang ve Park-Poaps, 2010; Cho ve Workman, 2011). Dolayısıyla iki boyutlu bu yapısal özellik, açıklayıcı faktör analizi ile test edilmiştir. Ulaşılan test sonuç ve değerleri tablo 2'de gösterilmektedir. 
Tablo 2. Moda Liderliği AFA Sonuçları

\begin{tabular}{|c|c|c|c|c|c|c|}
\hline \multirow{2}{*}{\multicolumn{2}{|c|}{ Faktör/Maddeler }} & \multicolumn{3}{|c|}{ Faktör Yük Değerleri } & \multirow{2}{*}{$\alpha$} & \multirow{2}{*}{$\begin{array}{c}\text { Ortak Faktör } \\
\text { Varyans }\end{array}$} \\
\hline & & 1 & 2 & 3 & & \\
\hline \multirow{4}{*}{ Fikir Liderliği } & Fikir3 & 0,817 & - & - & \multirow{4}{*}{0,73} & 0,690 \\
\hline & Fikir4 & 0,742 & - & - & & 0,629 \\
\hline & Fikir5 & 0,705 & - & - & & 0,656 \\
\hline & Fikir2 & 0,592 & - & - & & 0,535 \\
\hline \multirow{3}{*}{ Modayı Takip } & Takip6 & - & 0,810 & - & \multirow{3}{*}{0,75} & 0,660 \\
\hline & Takip5 & - & 0,803 & - & & 0,698 \\
\hline & Takip4 & - & 0,699 & - & & 0,632 \\
\hline \multirow{3}{*}{$\begin{array}{l}\text { Moda Ürün } \\
\text { Alma }\end{array}$} & Alma3 & - & - & 0,815 & \multirow{3}{*}{0,71} & 0,700 \\
\hline & Alma2 & - & - & 0,772 & & 0,658 \\
\hline & Alma1 & - & - & 0,733 & & 0,537 \\
\hline \multicolumn{2}{|c|}{ Açıklanan Varyans (\%) } & $\begin{array}{c}22,92 \\
7\end{array}$ & 21,242 & 19,795 & - & - \\
\hline \multicolumn{2}{|c|}{ Toplam A. Varyans (\%) } & \multicolumn{3}{|c|}{63,963} & & \\
\hline
\end{tabular}

Moda liderliğine yönelik yürütülen açıklayıcı faktör analizi sonucundan moda fikir liderliği ve moda yenilikçiliği şeklindeki iki boyutlu yapının bu çalışmada üç boyutlu bir yapı şeklinde oluştuğu belirlenmiştir. Moda yenilikçiliği değişkeni kendi içinde iki alt boyuta ayrılmıştır. Elde edilen boyutlar; moda fikir liderliği, modayı takip etme ve moda ürün satın alma şeklinde yeniden adlandırılmıştır. Açıklayıcı faktör analizi test değerleri incelendiğinde, KMO değerinin 0,80 ve Barttlett's test değerinin anlamlı olduğu belirlenmiştir. Maddelerin faktör yük değerleri 0,50 'den büyük olduğu, güvenilirlik değerinin 0,70 'den büyük olduğu ve açıklanan varyans değerinin 0,50 'den büyük olduğu belirlenmiştir. Elde edilen test değerleri sonuçlarına göre, iç tutarlılık ve yapısal geçerliliğin sağlandığı ifade edilebilmektedir.

Tüketicilerin satın alma stillerinden olan hedonik ve faydacı tüketim stilleri, tek boyutlu olarak incelenen iki farklı değişkendir. İki değişken birlikte açıklayıcı faktör analizine tabi tutulmuş ve elde edilen test sonuçları tablo 3 'te sunulmuştur.

Tablo 3. Tüketim Stilleri AFA Sonuçları

\begin{tabular}{|c|c|c|c|c|c|}
\hline \multirow{2}{*}{\multicolumn{2}{|c|}{ Faktör/Maddeler }} & \multicolumn{2}{|c|}{ Faktör Yük Değerleri } & \multirow{2}{*}{$\alpha$} & \multirow{2}{*}{$\begin{array}{c}\text { Ortak Faktör } \\
\text { Varyans }\end{array}$} \\
\hline & & 1 & 3 & & \\
\hline \multirow{3}{*}{$\begin{array}{l}\text { Hedonik } \\
\text { Tüketim }\end{array}$} & Hedonik5 & 0,884 & & \multirow{3}{*}{0,81} & 0,785 \\
\hline & Hedonik6 & 0,871 & & & 0,760 \\
\hline & Hedonik4 & 0,793 & & & 0,630 \\
\hline \multirow{3}{*}{$\begin{array}{l}\text { Faydacı } \\
\text { Tüketim }\end{array}$} & Faydac13 & & 0,881 & \multirow{3}{*}{0,78} & 0,776 \\
\hline & Faydac12 & & 0,878 & & 0,775 \\
\hline & Faydac14 & & 0,742 & & 0,575 \\
\hline \multicolumn{2}{|c|}{ Açıklanan Varyans (\%) } & 36,660 & 35,023 & - & - \\
\hline \multicolumn{2}{|c|}{ Toplam A. Varyans (\%) } & \multicolumn{2}{|c|}{71,683} & & \\
\hline
\end{tabular}

Tüketim stillerine yönelik yürütülen açıklayıcı faktör analizi sonucunda; hedonik tüketim ve faydacı tüketim iki boyutlu bir yapıda ayrımlanmıştır. Açıklayıcı faktör analizi test değerleri incelendiğinde, KMO değerinin 0,670 ve Barttlett's test değerinin anlamlı olduğu belirlenmiştir. Maddelerin faktör yük değerleri 0,50'den büyük olduğu, güvenilirlik değerinin 0,70 'den büyük olduğu ve açıklanan varyans değerinin 0,50 'den büyük olduğu belirlenmiştir. 
Elde edilen test değerleri sonuçlarına göre, bu faktör analizinde iç tutarlılık ve yapısal geçerliliğin sağlandığ görülmüştür.

\subsection{Doğrulayıcı Faktör Analizi}

Doğrulayıcı faktör analizi, gizil değişkenler ile ilgili kuramların test edilmesine dayanan daha önceden tanımlanmış ve sınırlandırılmış bir yapının bir model olarak doğrulanıp doğrulanmadığının test edilmesinde kullanılan bir analiz modelidir (Çokluk vd., 2014). Açıklayıcı faktör analizi sonucunda elde edilen yapıların doğrulanması amacıyla moda liderliği ve tüketim stillerine yönelik yapısal eşitlik modeli yürütülmüştür. Tipik bir yapısal eşitlik modelinde ölçme modeli ve yapısal model olmak üzere iki aşama bulunmaktadır (Çokluk vd., 2014). İzleyen başlıklarda sözü edilen bu iki aşamaya ilişkin bulgulara yer verilmektedir.

\section{4. Ölçme Modelinin Testi}

Gözlenen değişkenleri gizil değişkenlere doğrulayıcı faktör analizi yoluyla bağlama şeklinde uygulanan ölçme modeli (Çokluk vd., 2014) sonuçları şekil 2'de yansıtılmaktadır.

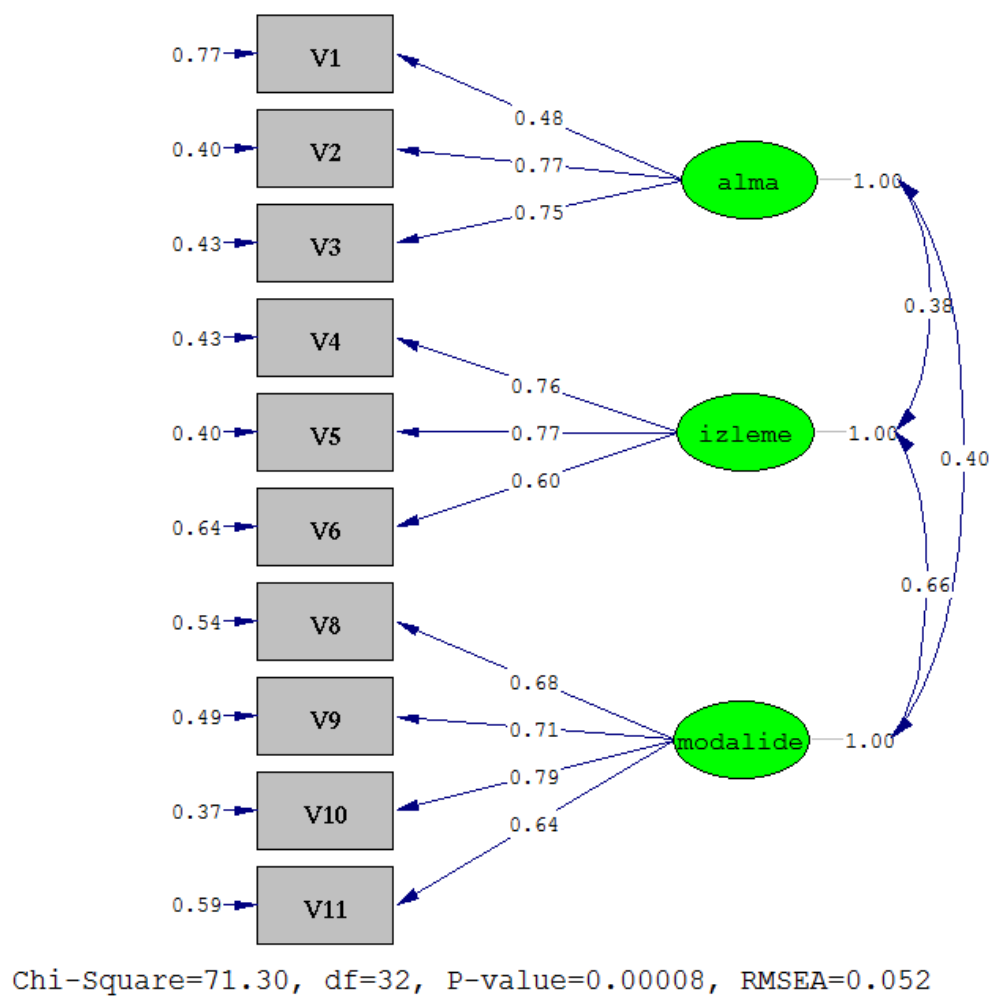

Şekil 2. Moda Liderliği Birinci Düzey DFA

Birinci düzey doğrulayıcı faktör analizi sonucunda ulaşılan değerler ve uyum iyiliği değerleri tablo 4'te gösterilmektedir. 
Tablo 4. Moda Liderliği DFA Sonuçları

\begin{tabular}{|c|c|c|c|c|c|c|}
\hline \multicolumn{2}{|c|}{ Gizil/ Örtük Değişkenler } & $\boldsymbol{K}$ & T Değerleri & $\mathbf{P .}$ & CR & AVE \\
\hline \multirow{3}{*}{$\begin{array}{l}\text { Moda Ürün } \\
\text { Alma }\end{array}$} & Alma1 & 0,48 & 9,38 & $<0,01$ & \multirow{3}{*}{0,71} & \multirow{3}{*}{0,46} \\
\hline & Alma2 & 0,77 & 14,82 & $<0,01$ & & \\
\hline & Alma3 & 0,75 & 14,53 & $<0,01$ & & \\
\hline \multirow{3}{*}{ Modayı Takip } & İzleme4 & 0,76 & 16,39 & $<0,01$ & \multirow{4}{*}{0,80} & \multirow{4}{*}{0,58} \\
\hline & İzleme5 & 0,77 & 16,80 & $<0,01$ & & \\
\hline & İzleme6 & 0,60 & 12,59 & $<0,01$ & & \\
\hline \multirow{4}{*}{ Fikir Liderliği } & Fikir3 & 0,68 & 14,90 & $<0,01$ & & \\
\hline & Fikir4 & 0,71 & 15,96 & $<0,01$ & \multirow{3}{*}{0,80} & \multirow{3}{*}{0,50} \\
\hline & Fikir5 & 0,79 & 18,33 & $<0,01$ & & \\
\hline & Fikir6 & 0,64 & 13,80 & $<0,01$ & & \\
\hline \multicolumn{2}{|c|}{ Uyum İyiliği Değerleri } & \multicolumn{5}{|c|}{$\begin{array}{ll}\chi^{2}=71,30(\mathrm{P}=0.00), \mathrm{Df}=32, & \chi^{2} / \mathrm{Df}=2,22, \mathrm{GFI}=0.97, \\
\mathrm{AGFI}=0.95, \quad \mathrm{NNFI}=0.98, & \mathrm{RMSEA}=0.052\end{array}$} \\
\hline
\end{tabular}

Açıklayıcı faktör analizinin ardından üç faktörlük bir yap1 sergilediği belirlenen moda liderliği değişkenine ilişkin yürütülen doğrulayıcı faktör analizi sonucunda, faktör yük değerlerinin bir değişken dışında (alma1 0,48) 0,50 değerinden büyük olduğu, gözlem değişkenlerine ilişkin tüm $\mathrm{t}$ değerlerinin anlamlı olduğu $(\mathrm{p}<0,01)$ belirlenmiştir. Manuel olarak hesaplanan CR (composite reliability) ve açıklanan varyans değerlerinin de kabul sınırları içerisinde olduğu görülmektedir. Doğrulayıcı faktör analizi uyum değerleri incelendiğinde $\left(\chi^{2}=71,30(\mathrm{P}=0.00), \mathrm{Df}=32, \chi^{2} \quad / \mathrm{Df}=2,22, \mathrm{GFI}=0.97\right.$, AGFI = 0.95, NNFI $=0.98, \quad$ RMSEA $=0.052)$ veri ve model arasındaki uyumun iyi olduğu ifade edilebilmektedir.

Moda liderliği değişkeninin yanı sıra, tüketim stili değişkeni de doğrulayıcı faktör analizine tabi tutulmuş ve ölçme modeli sonuçları şekil 3'te yansıtılmıştır.

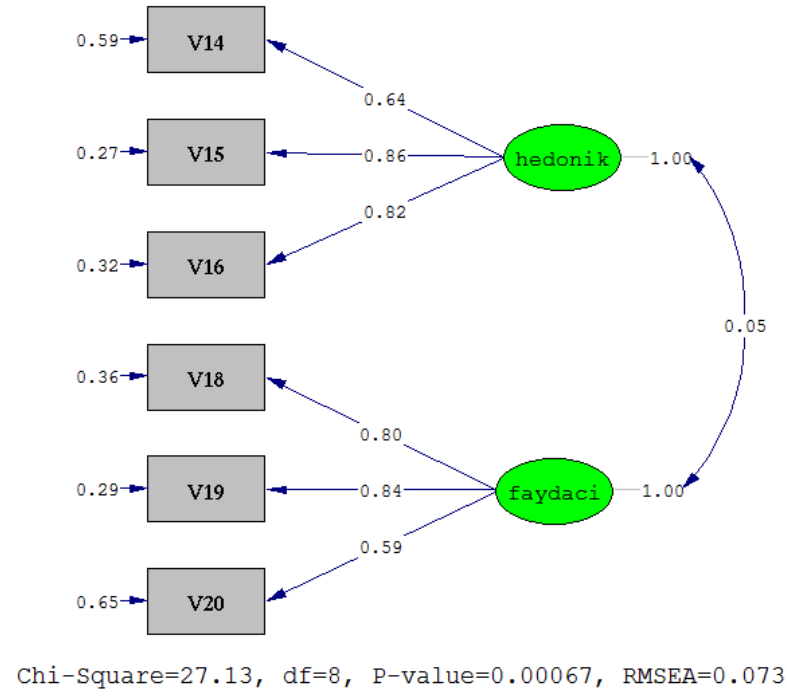

Şekil 3. Tüketim Stilleri DFA 
Ayrıca, tüketim stili değişkeni için birinci düzey doğrulayıcı faktör analizi sonucunda ulaşılan değerler ve uyum iyiliği değerleri tablo 5 'te gösterilmektedir.

Tablo 5. Tüketim Stilleri DFA Sonuçları

\begin{tabular}{|c|c|c|c|c|c|c|}
\hline \multicolumn{2}{|c|}{ Gizil/ Örtük Değişkenler } & 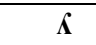 & T Değerleri & P. & $\mathbf{C R}$ & AVE \\
\hline \multirow{3}{*}{$\begin{array}{l}\text { Hedonik } \\
\text { Tüketim }\end{array}$} & Hedonik4 & 0,64 & 14,09 & $<0,01$ & \multirow{3}{*}{0,82} & \multirow{3}{*}{0,60} \\
\hline & Hedonik5 & 0,86 & 19,31 & $<0,01$ & & \\
\hline & Hedonik6 & 0,82 & 18,51 & $<0,01$ & & \\
\hline \multirow{3}{*}{$\begin{array}{l}\text { Faydacı } \\
\text { Tüketim }\end{array}$} & Faydac18 & 0,80 & 16,85 & $<0,01$ & \multirow{3}{*}{0,79} & \multirow{3}{*}{0,56} \\
\hline & Faydac19 & 0,84 & 17,71 & $<0,01$ & & \\
\hline & Faydac110 & 0,59 & 12,45 & $<0,01$ & & \\
\hline \multicolumn{2}{|c|}{ Uyum İyiliği Değerleri } & \multicolumn{5}{|c|}{$\begin{array}{l}\chi^{2}=27,13(\mathrm{P}=0.00), \mathrm{Df}=8, \chi^{2} / \mathrm{Df}=3,39, \mathrm{GFI}=0.98, \\
\mathrm{AGFI}=0.95, \mathrm{NNFI}=0.96, \mathrm{RMSEA}=0.073\end{array}$} \\
\hline
\end{tabular}

Açıklayıcı faktör analizinin ardından iki faktörlü yapı sergileyen hedonik ve faydacı tüketim stillerine ilişkin yürütülen doğrulayıcı faktör analizi sonucunda, faktör yük değerlerinin 0,50 değerinden büyük olduğu, gözlem değişkenlerine ilişkin tüm $t$ değerlerinin anlamlı olduğu $(p<0,01)$ belirlenmiştir. Manuel olarak hesaplanan CR (composite reliability) ve açıklanan varyans değerlerinin de kabul sınırları içerisinde olduğu görülmektedir. Doğrulayıcı faktör analizi uyum değerleri incelendiğinde $\left(\chi^{2}=71,30(\mathrm{P}=0.00), \mathrm{Df}=32, \chi^{2} / \mathrm{Df}=2,22\right.$, GFI = $0.97, \mathrm{AGFI}=0.95, \mathrm{NNFI}=0.98, \quad \mathrm{RMSEA}=0.052)$ veri ve model arasindaki uyumun iyi olduğu ifade edilebilmektedir.

\subsection{Yapısal Modelin Testi ve Elde Edilen Bulgular}

Yapısal eşitlik modelinin ilk aşaması olan ölçme modelinin testinden sonra, ikinci aşamasında gizil değişkenleri birbirlerine eş zamanlı olarak eşitlik sistemleri ile bağlamada uygulanan yapısal model test edilmektedir (Çokluk vd., 2014). Yapısal modelin test edilmesinden önce, değişkenler arasındaki ilişkilerin test edilmesi amacıyla korelasyon analizi yürütülmüştür. Korelasyon analizi sonuçları tablo 6'da görülebilmektedir.

Tablo 6. Tüketim Stilleri ile Moda Liderliği Arasındaki İlişkinin Testi

\begin{tabular}{|c|l|l|c|c|c|c|c|}
\hline \multicolumn{2}{|l|}{ Değişkenler } & $\mathbf{1}$ & $\mathbf{2}$ & $\mathbf{3}$ & $\mathbf{4}$ & $\mathbf{5}$ \\
\hline $\mathbf{1}$ & $\begin{array}{l}\text { Moda Ürün } \\
\text { Alma }\end{array}$ & Pearson Correlation & 1 & & & & \\
\hline & Sig. (2-tailed) & & & & & \\
\hline $\mathbf{2}$ & \multirow{2}{*}{ Modayı Takip } & Pearson Correlation &, $236^{* *}$ & 1 & & & \\
\hline & & Sig. (2-tailed) &, 000 & & & & \\
\hline $\mathbf{3}$ & $\begin{array}{l}\text { Moda Fikir } \\
\text { Liderliği }\end{array}$ & Pearson Correlation &, $335^{* *}$ &, $434^{* *}$ & 1 & & \\
\hline & Sig. (2-tailed) &, 000 &, 000 & & & \\
\hline $\mathbf{4}$ & $\begin{array}{l}\text { Hedonik } \\
\text { Tüketim }\end{array}$ & Pearson Correlation &, $186^{* *}$ &, $495^{* *}$ &, $320^{* *}$ & 1 & \\
\hline & Sig. (2-tailed) &, 000 &, 000 &, 000 & & \\
\hline $\mathbf{5}$ & $\begin{array}{l}\text { Faydacı } \\
\text { Tüketim }\end{array}$ & Pearson Correlation &, 043 &, $096^{*}$ &, $259^{* *}$ &, 078 & 1 \\
\hline & Sig. (2-tailed) &, 360 &, 042 &, 000 &, 097 & \\
\hline$* * *$ & & & & & \\
\hline
\end{tabular}

Korelasyon tablosu incelendiğinde; bağımsız değişkenler olan hedonik ve faydacı tüketim ile bağımlı değişkenler moda ürün satın alma, modayı takip etme ve moda fikir liderliği arasında istatistiksel olarak anlamlı $(\mathrm{p}<0,05)$ ilişkiler olduğu görülmektedir. Faydacı tüketim ile moda ürün satın alma ve modayı takip etme değişkenleri arasında anlamlı ilişkiler bulunmuyorken, faydacı tüketim moda fikir liderliği ile anlamlı ilişkiye sahiptir. Bu doğrultuda araştırma hipotezlerinin de test edileceği yapısal model test edilmeye çalışılmıştır. Bu bağlamda elde edilen test değerleri sonuçları şekil 4'te gösterilmektedir. 


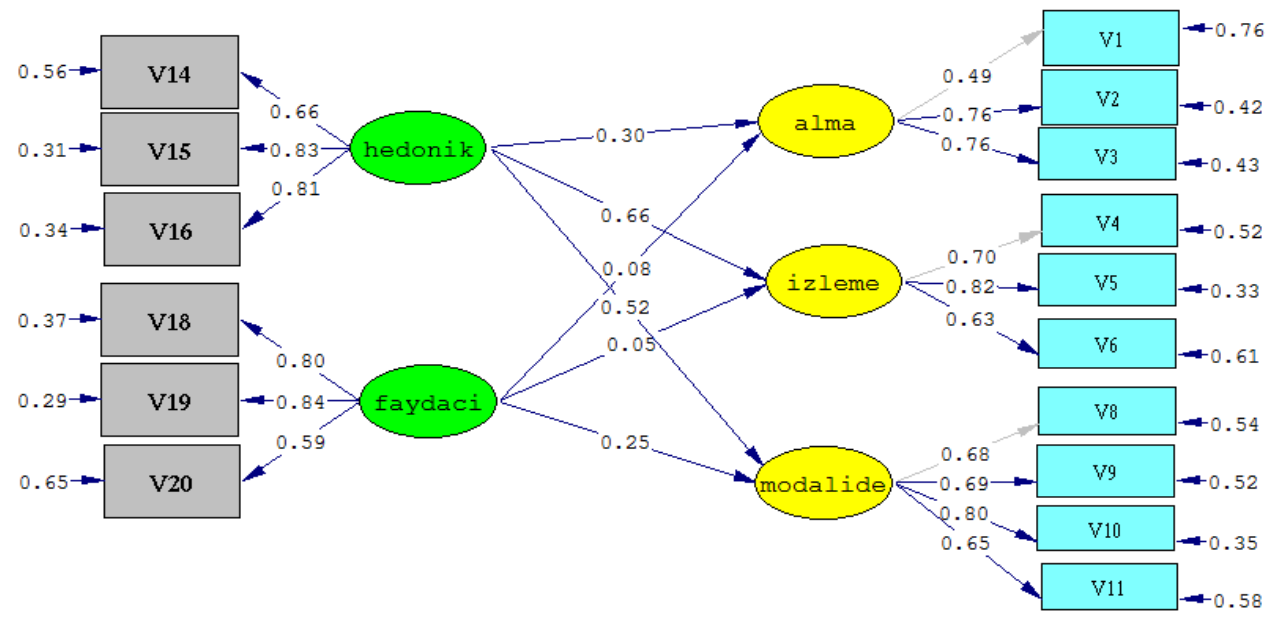

Chi-Square=260.84, df=97, P-value=0.00000, RMSEA=0.061

\section{Şekil 4. Yapısal Modelin Testi}

$\mathrm{Bu}$ araştırmada beş ayrı hipotez test edilmek amacıyla öne sürülmüştür. Ancak, literatürde iki boyutlu olarak incelenen moda liderliği değişkeninin, bu çalışmada açıklayıcı faktör analizi sonrasında moda ürün satın alma, modayı takip etme ve moda fikir liderliği olarak üç boyutlu yap1 sergilemesi nedeniyle test edilmek üzere bir hipotez daha eklenmiş ve test edilecek hipotez sayısı altıya çıkmıştır. Moda yenilikçiliği boyutu, moda ürün satın alma ve modayı takip etme şeklinde yeninden ifade edilmiştir. Test edilecek hipotezler yenilenerek aşağıdaki şekilde belirtilmiştir:

$\mathrm{H}_{1}$ : Hedonik tüketim moda ürün satın almayı etkilemektedir

$\mathrm{H}_{2}$ : Faydacı tüketim moda ürün satın almayı etkilemektedir.

$\mathrm{H}_{3}$ : Hedonik tüketim modayı takip etmeyi etkilemektedir.

$\mathrm{H}_{4}$ : Faydacı tüketim modayı takip etmeyi etkilemektedir.

$\mathrm{H}_{5}$ : Hedonik tüketim moda fikir liderliğini etkilemektedir.

$\mathrm{H}_{6}$ : Faydacı tüketim modayı fikir liderliğini etkilemektedir.

$\mathrm{H}_{7}$ : Bireyler faydacı ve hedonik tüketim ile moda liderliği açısından doğal kümelere sahiptir. 
Tablo 7. Yapısal Model Test Değerleri

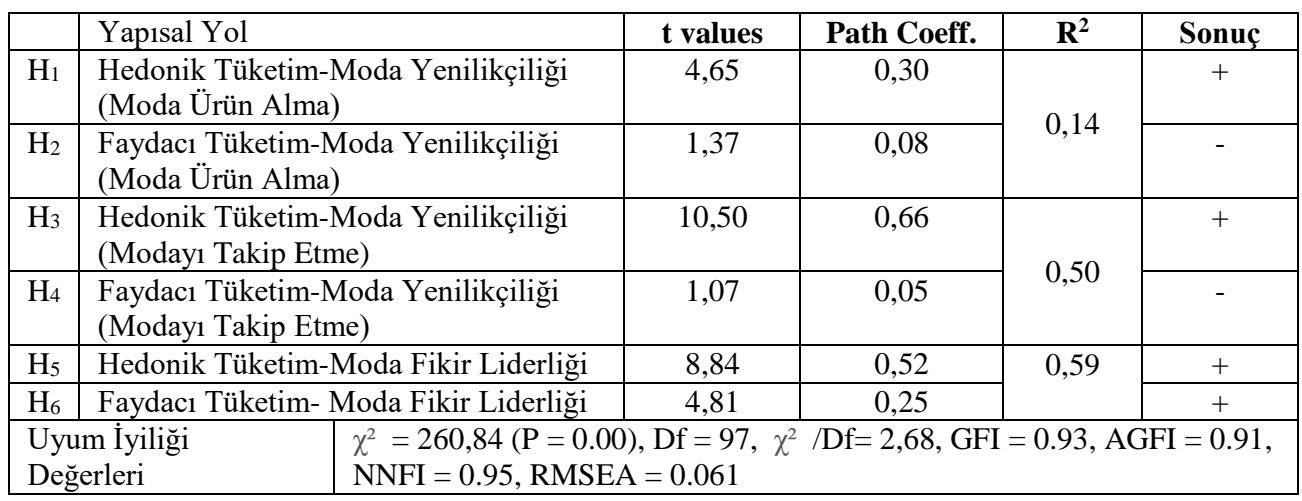

Bağımsız değişkenlerin bağımlı değişken üzerindeki etkisinin incelendiği yapısal modelde, hedonik tüketimin moda ürün satın almayı, modayı takip etmeyi ve moda fikir liderliğini etkilediği belirlenmiştir. $\mathrm{Bu}$ doğrultuda, $\mathrm{H}_{1}, \mathrm{H}_{2}$ ve $\mathrm{H}_{5}$ hipotezleri kabul edilmiştir. Faydac1 tüketimin ise, moda ürün satın almayı ve modayı takip etmeyi etkilemediği; moda fikir liderliğini ise etkilediği belirlenmiştir. $\mathrm{Bu}$ doğrultuda, $\mathrm{H}_{2}$ ve $\mathrm{H}_{4}$ hipotezleri reddedilirken $\mathrm{H}_{5}$ hipotezleri kabul edilmiştir. Yapısal modelin uyum değerleri incelendiğinde $\chi^{2}=260,84(\mathrm{P}=$ $0.00), \mathrm{Df}=97, \chi^{2} / \mathrm{Df}=2,68, \mathrm{GFI}=0.93, \mathrm{AGFI}=0.91, \mathrm{NNFI}=0.95, \mathrm{RMSEA}=0.061$ tüm değerlerin kabul sınırları içerisinde olduğu veri ve model arasında iyi bir uyum olduğu ifade edilebilmektedir.

\subsection{Kümeleme Analizi Bulguları}

Tüketim stilleri ve moda liderliği çerçevesinde değişkenler bazında katılımcıların gruplandırılması açısından kümeleme analizi kullanılmıştır. Kümeleme analizi genel olarak, belirli özelliklere göre birimlerin benzerliklerini ortaya koymak ve bu benzerlikleri esas alarak birimleri doğru kategoriler içerisinde sınıflandırmayı amaçlamaktadır. Küme sayısının belirlenmiş olması ya da küme sayısına karar verilmiş olduğu durumlarda tercih edilmesi önerilen bir analizdir (Çokluk vd., 2014). Bu çalışma kapsamında düşük, orta ve yüksek moda liderliği ve tüketim stilleri kapsamında kümeleme yapılaması kararlaştırılmış ve örnek sayısının 250> olması nedeniyle hiyerarşik olmayan kümeleme analizi olan ' $\mathrm{k}$-means' kümeleme analizi kullanılmıştır. Öncelikle değişkenlere ait ortalamaların z skorlarına son küme merkezleri ve her bir kümede yer alan birim sayıları belirlenmiştir.

Son küme merkezleri, her bir son küme içindeki değişkenlerin ortalamalarının z-skorları hesaplanarak elde edilmektedir. Son küme merkezleri her bir kümeye yönelik birimlerin özelliklerini göstermektedir. Aşağıdaki tablo 8'de, son küme merkezlerine ilişkin değerler gösterilmektedir.

Tablo 8. Son Küme Merkezleri

\begin{tabular}{|l|c|c|c|}
\hline \multirow{2}{*}{ Değişkenler } & \multicolumn{3}{|c|}{ Kümeler } \\
\cline { 2 - 4 } & $\mathbf{1}$ & $\mathbf{2}$ & $\mathbf{3}$ \\
\hline Hedonik Tüketim & 0,74900 & $-0,88383$ & $-0,09250$ \\
\hline Faydacı Tüketim & 0,51508 & 0,36566 & $-1,16946$ \\
\hline Moda Yenilikçiliği Alma & 0,28619 & $-0,49323$ & 0,14133 \\
\hline Moda Yenilikçiliği İzleme & 0,66863 & $-0,80780$ & $-0,06121$ \\
\hline Moda Fikir Liderliği & 0,66775 & $-0,62277$ & $-0,27012$ \\
\hline N & $183(\% 40,6)$ & $142(\% 31,6)$ & $125(\% 27,8)$ \\
\hline
\end{tabular}


Hiyerarşik olmayan kümeleme analizinde ANOVA test değerleri kümeleme analizi çerçevesinde incelenen değişkenlerin kümeleme analizinde anlamlılığını test etmektedir. Araştırma kapsamında incelenen değişkenlerin kümeleme analizi kapsamında anlamlı ve küme çözümlemesine katkı sağladıkları görülmektedir. ANOVA değerleri tablo 9'da gösterilmektedir.

Tablo 9. ANOVA Değerleri

\begin{tabular}{|l|c|c|c|c|c|c|}
\hline \multirow{2}{*}{ Değişkenler } & \multicolumn{2}{|c|}{ Kümeler } & \multicolumn{2}{|c|}{ Hata } & \multirow{2}{*}{ F } & p \\
\cline { 2 - 5 } & $\begin{array}{c}\text { Ort. } \\
\text { Karesi }\end{array}$ & SD. & $\begin{array}{c}\text { Ort. } \\
\text { Karesi }\end{array}$ & SD. & & \\
\hline Hedonik Tüketim & 107,328 & 2 & 0,524 & 447 & 204,724 & 0,000 \\
\hline Faydacı Tüketim & 119,245 & 2 & 0,471 & 447 & 253,206 & 0,000 \\
\hline Moda Yenilikçiliği Alma & 26,016 & 2 & 0,888 & 447 & 29,295 & 0,000 \\
\hline $\begin{array}{l}\text { Moda Yenilikçiliği } \\
\text { İzleme }\end{array}$ & 87,470 & 2 & 0,613 & 447 & 142,667 & 0,000 \\
\hline Moda Fikir Liderliği & 72,896 & 2 & 0,678 & 447 & 107,466 & 0,000 \\
\hline
\end{tabular}

Küme dağılımlarına ilişkin son küme merkezleri incelendiğinde katılımcıların 3 küme çözümü şeklinde gruplandırıldığı ve her bir kümenin anlamlı bir şekilde dağılım gösterdiği görülmektedir. Küme çözümündeki gruplandırmalar incelendiğinde, birinci kümede yer alan katılımcıların yüksek düzeyde hedonik satın alma, yüksek düzeyde faydacı satın alma özelliği ile moda ürün satın alma, modayı takip etme ve moda fikir liderliği özellikleri yüksek olan bireylerden oluştuğu görülmektedir. İkinci kümede yer alan katılımcılar, faydacı tüketim eğilimi yüksek olan ancak, hedonik satın alma, moda ürün satın alma, modayı takip etme ve moda fikir liderliği özellikleri düşük olan bireylerden oluştuğu görülmektedir. Üçüncü kümede yer alan bireyler ise, moda ürünlerle ilgili olan ancak hedonik satın alma, faydacı satın alma, modayı takip etme ve moda fikir liderliği özellikleri düşük olan bireylerden oluşmaktadır.

Final Cluster Centers

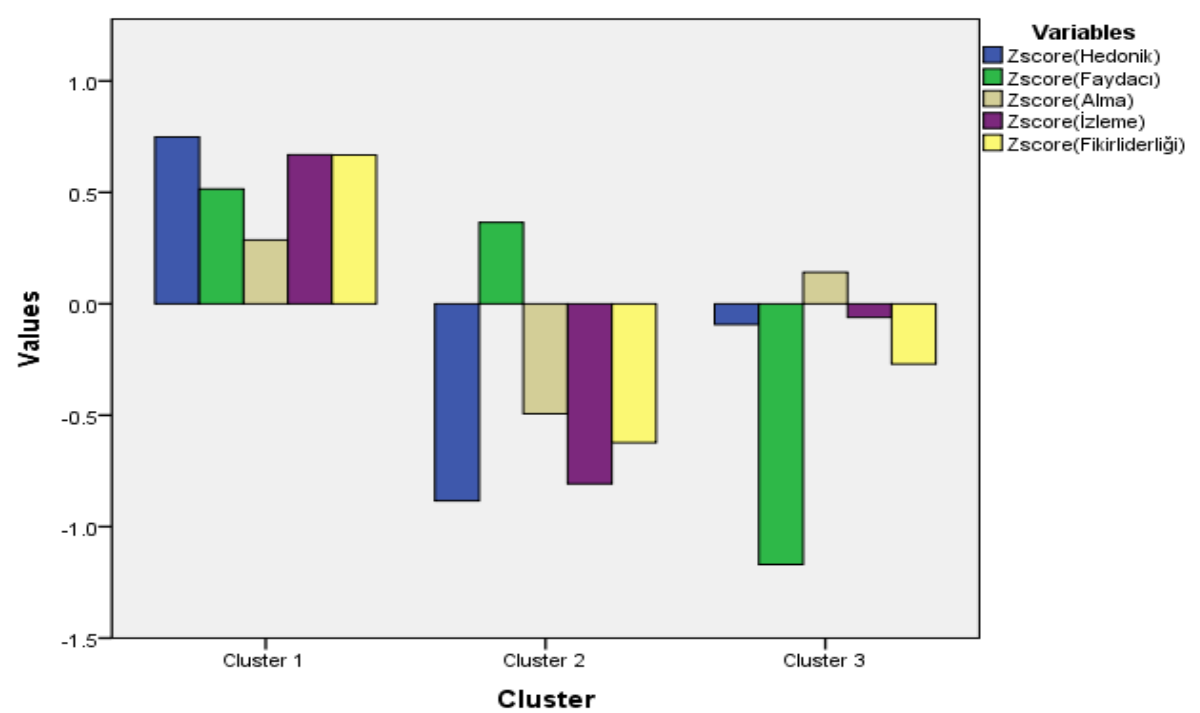

Grafik 3. Küme Dağılımları 
Kümeleme analizi sonucunda, ANOVA değerleri ve son küme dağılımları incelendiğinde kümeleme analizi açısından değişkenlerin anlamlı ve küme çözümlemesine katkı sağladıkları ifade edilebilmektedir. Bu doğrultuda, $\mathrm{H}_{6}$ hipotezi kabul edilmiş, bireylerin satın alma stilleri ve moda liderliği özellikleri bakımından benzer gruplara ayrılabildikleri ifade edilebilmektedir.

\section{SONUÇ \& ÖNERILER ve KISITLAR}

Literatürdeki araştırmaların bulguları göz önüne alındığında; hedonik tüketim eğilimi yüksek düzeyde olan tüketicilerin, moda yenilikçiliği ve moda fikir liderliği açısından yüksek düzeyde olan bireyler olduğu; bunun yanında faydacı tüketim eğilimi yüksek düzeyde olan bireylerin ise, moda liderliği ve moda fikir liderliği açısından düşük düzeye sahip bireyler olduğu görülmektedir. Aynı zamanda bu çalışmalarda, alışveriş biçimlerinin moda liderliği ile anlamlı yönde bir ilişkiye sahip olduğu ifade edilmektedir (Kang ve Park-Poaps, 2010). Erciş ve Türk (2012) çalışmalarında, sosyal yenilikçiliğin moda ürün satın alma üzerinde etkili olduğunu, hedonik yenilikçiliğin ise etkili olmadığını belirlemişlerdir. Yenilikçi bireylerin yenilikçi olmayanlara kıyasla kıyafet satın alımlarında havalı hedonik tutumlara sahip oldukları ve havalı ürünlerin yenilikçi ve faydacı değerlerinin gençler yönelik birbirleriyle ilgili olmadığı belirlenmiştir (Noh vd., 2014). Moda ürünler kapsamında hedonik tüketim eğilimlerinin moda ürünlerle ilişkili olduğu ifade edilmektedir (Miller, 2013). Kang ve ParkPoaps (2010) moda liderliği boyutları; moda yenilikçiliği ve moda fikir liderliği ile alışveriş tarzlarının ilişkisel olarak inceledikleri çalışmalarında, moda yenilikçiliğinin hedonik satın alma (fikir edinme amaçlı, maceracı, ve değer elde etme) ile moda yenilikçiliğinin ilişkili olduğu ve moda fikir liderliğinin ise faydacı satın alma ile ilişkisi olduğu belirlenmiştir.

$\mathrm{Bu}$ çalışmada, moda liderliği ve tüketim stilleri olan hedonik ve faydacı tüketim arasındaki olası ilişkiler incelenmiş ve araştırma birimleri çerçevesinde belirli özelliklerin betimlenmesi amaçlanmıştır. Literatürdeki çalışmalardan esinlenilerek adapte edilen ölçekler yoluyla yapılandırılmış anket yöntemiyle birimlerden veriler kolayda örnekleme ve yüzyüze görüşme yöntemiyle elde edilmiştir. Yapılan alan araştırması sonucunda elde edilen bulgular incelendiğinde; hedonik tüketim ve faydacı tüketim ile moda liderliği davranış özellikleri olan moda ürün satın alma, modayı takip etme ve moda fikir liderliği arasında istatistiksel olarak anlamlı ilişkiler belirlenmiştir. Bu ilişkileri test etmek üzere ileri sürülen hipotezlerin test edilmesine yönelik yapısal eşitlik modeli kullanılmıştır. Yapısal eşitlik analizi sonucunda; hedonik tüketim eğiliminin, moda ürün satın alma, modayı takip etme ve moda liderliğinin iyi bir açıklayıcısı olduğu belirlenmiştir. Ayrıca faydacı tüketim eğilimi ile ilgili testlerde faydacı tüketim eğiliminin moda ürün satın alma ve modayı takip etme üzerinde etkisi olmadığı; buna karşın moda liderliği davranışını etkilediği belirlenmiştir. Bu analizlere ek olarak yürütülen kmeans kümeleme analizi sonucunda değişkenlerin kümelenme açısından kullanılabilir olduğu ve bireylerin doğal küme yapılarına sahip oldukları belirlenmiştir.

Bireylerin ortak özellikler açısından gruplandırıldığı ve belirli değişkenler arasındaki ilişkilerin ortaya konulduğu bu çalışma; araştırmacılar ve hazır giyim sektöründe faaliyet gösteren işletmeler / uygulayıcılar açısından moda yönelimli pazarlama faaliyetlerinin anlaşılmasına çeşitli yönlerde katkılar sağlayabilecek niteliktedir. Araştırmada kolayda örnekleme yönteminin seçilmiş ve hedonik tüketimi ölçmede 22 maddeli ölçek yerine 7 maddeli ölçeğin tercih edilmiş olması, temel araştırma kısıtlarını oluşturmaktadır. Moda ve moda konusundaki tüketim araştırmalarının, güncelliğini koruyan ve ilgi çekici konulardan biri olması nedeniyle; gelecek araştırmacıların, nesiller, bölgeler, ülkeler ve değişik 
kültürler/alt kültürler arasında karşılaştırılmalar yapılabilmesine olanak sağlayacak daha geniş kapsamlı araştırmalar yapması beklenmektedir.

\section{KAYNAKÇA}

ABRAHAMSON, E. (1996). "Management Fashion”, Academy of Management Review, 21 (1): 254-285.

ATTMANN, J.T. JOHNSON, T.W. (2009). "Compulsive Consumption Behaviours: Invatigating Relationships Among Binge Eating, Compulsive Clothing Buying and Fashion Orientation”, International Journal of Consumer Studies, 33 (1): 267-273.

BABIN, B.J., DARDEN, W.R., \& GRIFFIN, M. (1994). "Work and/or Fun: Measuring Hedonic and Utilitarian Shopping Value", Journal of Consumer Research, 20 (4): 644-656.

BAIG, E. \& KHAN, S. (2010). "Emotional Satisfaction and Brand Loyalty in Hospitality Industry", International Bulletin of Business Administration, (7): 62-66.

BAILEY, L.R. \& SEOCK, Y.K. (2010). "The Relationship of Fashion Leadership, Fashion Magazine Content and Loyalty Tendency", Journal of Fashion Marketing and Management, 14 (1): 39-57.

CHO, S. \& WORKMAN, J.E. (2011). "Gender, Fashion Innovativeness and Opinion Leadership, and Need For Touch", Journal of Fashion Marketing and Management, 15 (3): 363-382.

ÇivíTÇİ, Ş. (2004). Moda Pazarlama, Asil Yayınları: Ankara.

ÇOKLUK, Ö., ŞEKERCİOĞLU, G., \& BÜYÜKÖZTÜRK, Ş. (2014). Sosyal Bilimler İçin Çok Değişkenli İstatistik SPSS ve Lisrel Uygulamaları, Pegem Akademi: Ankara.

ERCİŞ, A. \& TÜRK, B. (2012). “Tüketici Yenilikçiliğinin Moda Ürünleri Benimseme Eğilimi Üzerindeki Etkileri”, 1. İşletme Yönetimi ve Kurumsal Sosyal Sorumluluk Uluslararası Bilimsel Kongresi, 23-25 Kasım 2012, Bakü, Azerbaycan.

ERSUN, A.N. \& YILDIRIM, F. (2010). "Consumer Involvement and Brand Sensitivity of University Students in Their Choice of Fashion Products", Marmara Üniversitesi İiBF Dergisi, 18 (1): 313-333.

FLYNN, L.R., GOLDSMITH, R.E. \& EASTMAN, J.K. (1996). "Opinion Leaders and Opinion Seekers: Two New Measurement Scales", Journal of Academy of Marketing Science (JAMS), 24 (2):137-147.

GOLDSMITH, R.E., KIM, D., FLYNN, L.R. \& KIM, W.M. (2005). "Price Sensitivity and Innovativeness For Fashion Among Korean Consumers", The Journal of Social Psychology, 145 (5): 501-508.

GOLDSMITH, R.E. \& HOFACKER, C.F. (1991). "Measuring Consumer Innovativeness", Journal of the Academy of Marketing Science (JAMS), 19 (3): 209-221.

GOLDSMITH, R.E., FREIDEN, J. B., \& KILSHEIMER, J.C. (1993). "Social Values and Female Fashion Leadership: A Cross-Cultural Study", Psychology \& Marketing, 10 (5): 399-412. 
HARBEN, B. \& KIM, S. (2008). "Attitude Toward Fashion Advertisements with Political Content: Impact of Opinion Leadership and Perception of Advertisement Message", International Journal of Consumer Studies, 32 (1): 88-98.

HIZAL, G.S.G. (2003). “Bir İletişim Biçimi Olarak Moda: Modus”un Sınırları”, İletişim Araştırmaları, 1(1): 65-86.

IMRAN, R., SAEED, T., ANIS-UL-HAQ, M., \& FATIMA, A. (2010). “Organizational Climate As a Predictor of Innovative Work Behavior", African Journal of Business Management, 4(15), 3337.

JORDAN, Y. \& SIMPSON, M.N. (2006). "Consumer Innovativeness Among Females in Spesific Fashion Stores in the Menlyn Shopping Centre", Journal of Familiy Ecology and Consumer Sciences, 34 (1): 32-40.

JONES, M. A., REYNOLDS, K. E., \& ARNOLD, M. J. (2006). "Hedonic and Utilitarian Shopping Value: Investigating Differential Effects on Retail Outcomes", Journal of Business Research, 59(9), 974-981.

KIM, H.S. (2006). "Using Hedonic and Utilitarian Shopping Motivations to Profile Inner City Consumers", Journal of Shopping Center Research, 13 (1): 57-79.

LIM, E. A. C., \& Ang, S. H. (2008). "Hedonic vs. Utilitarian Consumption: A Cross-Cultural Perspective Based on Cultural Conditioning”, Journal of Business Research, 61(3), 225-232.

KNOX, S. \& WALKER, D. (2001). "Measuring and Managing Brand Loyalty", Journal of Strategic Marketing, 9 (1): 111-128.

LAW, K.M. ZHANG, Z.M. \& LEUNG, C.S. (2004). "Fashion Change and Fashion Consumption: The Chaotic Perspective", Journal of Fashion Marketing and Management, 8 (4): 362-374.

MCKINNEY, L.N., TRAYLOR, D.L. KINCADE, D.H. \& HOLLOMAN, L.O. (2004). "Selected Social Factors and Clothing Buying Behaviour Patterns of Black College Consumers", Int. Rev. Of Retail, Distribution and Consumer Research, 14 (4): 389406.

MEB (2008). Mesleki Eğitim ve Öğretim Sisteminin Güçlendirilmesi Projesi-Megep: Moda, Halkla İlişkiler ve Organize Hizmetleri, Ankara.

MICHON, R., YU, H., SMITH, D. \& CHEBAT, J.C. (2007). “The Shopping Experience of Female Fashion Leaders", International Journal of Retail \& Distribution Management, 35 (6): 488-501.

MILLER, K. (2013). "Hedonic Customer Responses to Fast Fashion and Replicas", Journal of Fashion Marketing and Management: An International Journal, 17 (2): 160-174.

MORGAN, L.R. \& BIRTWISTLE, G. (2009). “An Investigation of Young Consumers' Disposal Habits”, International Journal of Consumer Studies, 33 (1): 190-198.

NOH, M., RUNYAN, R. \& MOSIER, J. (2014). "Young Consumers' Innovativeness and Hedonic/Utilitarian Cool Attitudes", International Journal of Retail \& Distribution Management, 42 (4): 267-280. 
O'CASS, A. (2004). "Fashion Clothing Consumption: Antecedents and Consequences of Fashion Clothing Involvement”, European Journal of Marketing, 38 (7): 869-882.

OKADA, E. M. (2005). “Justification Effects on Consumer Choice of Hedonic and Utilitarian Goods", Journal of Marketing Research, 42(1), 43-53.

ÖZGÜL, E. (2011). “Tüketicilerin Sosyo-Demografik Özelliklerinin Hedonik Tüketim ve Gönüllü Sade Yasam Tarzları Açısından Değerlendirilmesi”, Ege Akademik Bakış, 11(1), 25-38.

PARK, H.J., BURNS, L.D. \& RABOLTS, N.J. (2007). "Fashion Innovativeness, Materialism, and Attitude Toward Purchasing Foreign Fashion Goods Online Across National Borders: The Moderating Effect of Internet Innovativeness", Journal of Fashion Marketing and Management, 11 (2): 201-214.

PATTERSON, F., KERRIN, M., \& GATTO-ROİSSARD, G. (2009). "Characteristics and Behaviours of Innovative People In Organisations", Literature Review prepared for the NESTA Policy \& Research Unit, 1-63.

PETERS, C. SHELTON, J.A. \& THOMAS, J.B. (2011). "Self-Concept and The Fashion Behavior of Women Over 50", International of Fashion Marketing and Management, 15 (3): 291-305.

RYOU, E.J. (2001). “A Study on Consumers' Characteristics According to Their Fashion Lidership-Focused on Body Cathexis, Self-Efficacy and Shopping Orientation", J.Kor.Soc. Cloth., 3 (5): 403-408.

SHOHAM, A. \& RUVIO, A. (2008). "Opinion Leaders and Foolowers: A Replication and Extension”, Psychology \& Marketing, 25 (3): 280-297.

STUDAK, C.M. \& WORKMAN, J.E. (2004). "Fashion Groups, Gender, and Boredom Proneness", International Journal of Consumer Studies, 28 (1): 66-74.

VERNETTE, E. (2004). "Targeting Women's Clothing Fashion Opinion Leaders In Media Planning: An Application for Magazines", Journal of Advertising Research, 44(1), 90-107.

WORKMAN, J.E. \& LEE, S.H. (2011). "Materialism, Fashion Consumers and Gender: A Cross-Cultural Study”, International Journal of Consumer Studies, 35 (1): 50-57.

WORKMAN, J.E. \& STUDAK, C.M. (2006). "Fashion Consumers and Fashion Problem Recognition Style”, International Journal of Consumer Studies, 30 (1): 75-84.

VIEIRA, V.A. (2009). “An Extended Theoretical Model od Fashion Clothing Involvement”, Journal of Fashion Marketing and Management, 13. (2): 179-200.

VIRVILAITE, R. SALADIENE, V. \& ZYINKLYTE, J. (2011). "The Impact of External and Internal Stimuli on Impulsive Purchasing”, Economics and Management, 16 (1): 1329-1336. 
Ek-Araştırmada Kullanılan Anket Formu

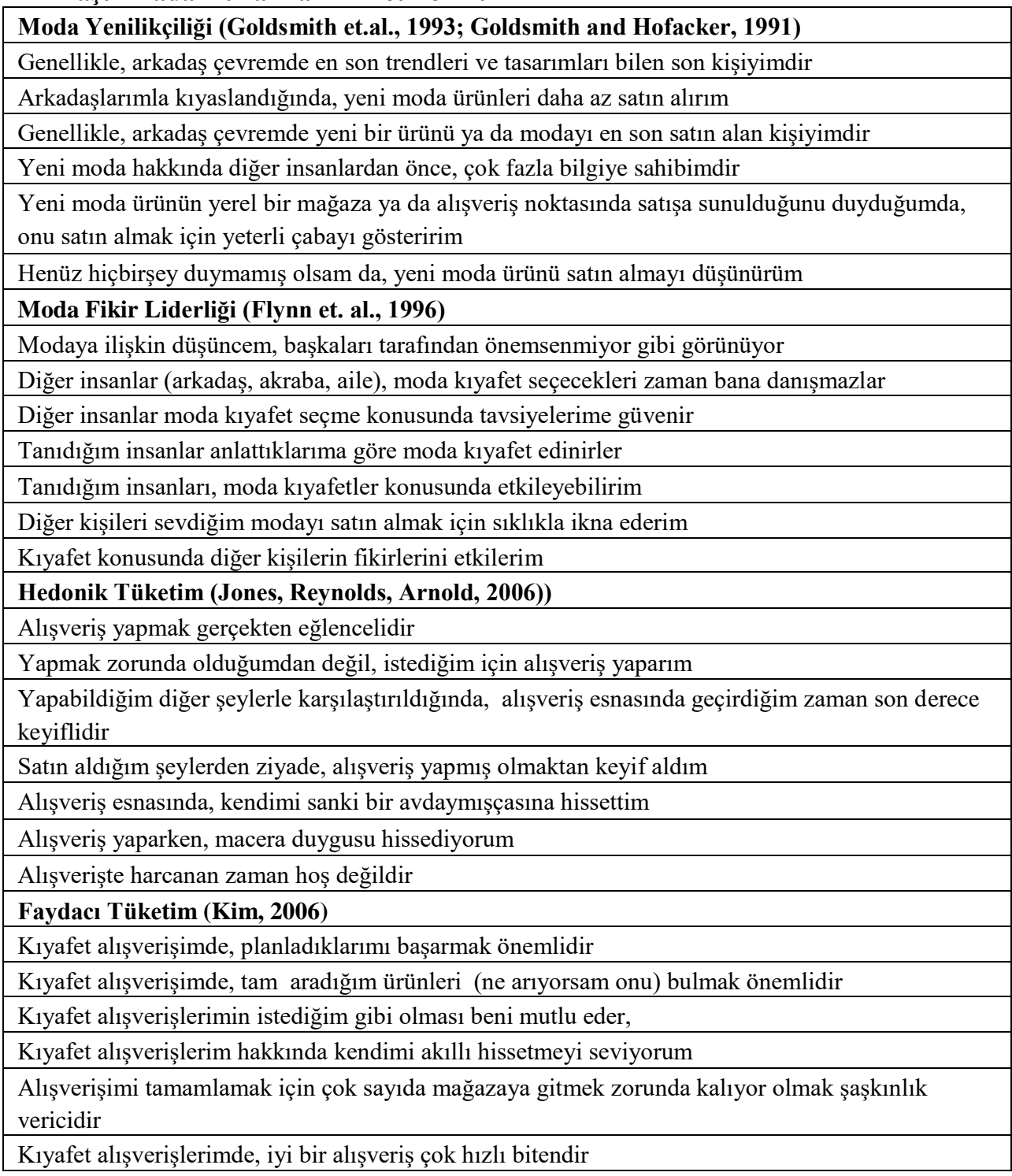

